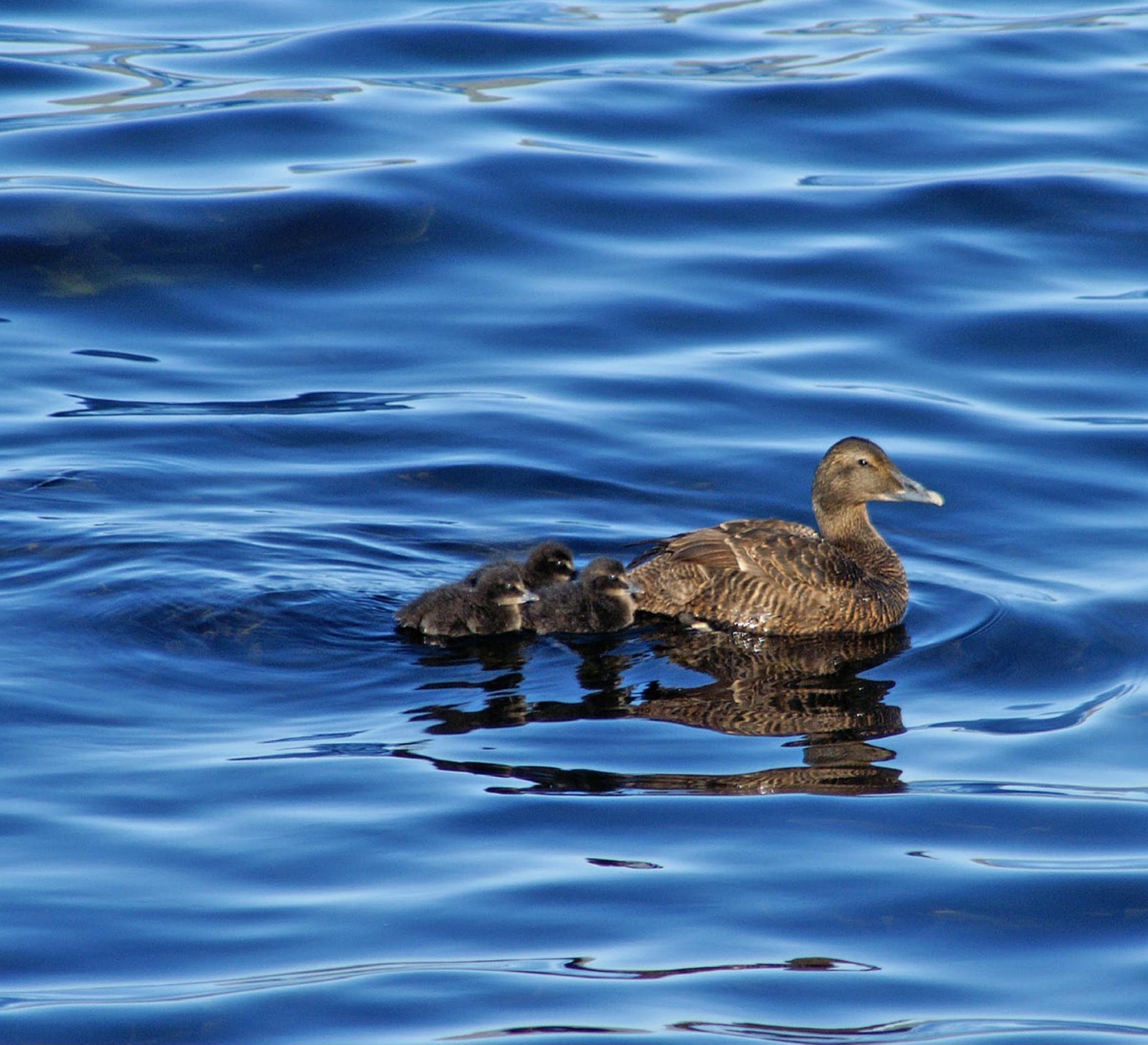

\title{
Broedsucces van kustbroedvogels in de Waddenzee in 2018
}



Broedsucces van kustbroedvogels in de Waddenzee in 2018 
Dit Technical report is gemaakt conform het Kwaliteitsmanagementsysteem (KMS) van de unit Wettelijke Onderzoekstaken Natuur \& Milieu, onderdeel van Wageningen University \& Research.

De WOT Natuur \& Milieu voert wettelijke onderzoekstaken uit op het beleidsterrein natuur en milieu. Deze taken worden uitgevoerd om een wettelijke verantwoordelijkheid van de Minister van Landbouw, Natuur en Voedselkwaliteit (LNV) te ondersteunen. We zorgen voor rapportages en data voor (inter)nationale verplichtingen op het gebied van agromilieu, biodiversiteit en bodeminformatie, en werken mee aan producten van het Planbureau voor de Leefomgeving zoals de Balans van de Leefomgeving.

\section{Disclaimer WOt-publicaties}

De reeks 'WOt-technical reports' bevat onderzoeksresultaten van projecten die kennisorganisaties voor de unit Wettelijke Onderzoekstaken Natuur \& Milieu hebben uitgevoerd.

WOt-technical report 183 is het resultaat van onderzoek gefinancierd door het ministerie van Landbouw, Natuur en Voedselkwaliteit (LNV). 


\section{Broedsucces van kustbroedvogels in de Waddenzee in 2018}

Koffijberg K. ${ }^{1}$, de Boer P. ${ }^{1}$, Geelhoed S.C.V. ${ }^{2}$, Nienhuis J. ${ }^{1}$, Oosterbeek K. ${ }^{1}$ \& Postma J. ${ }^{1}$

1 SOVON Vogelonderzoek Nederland

2 Wageningen Marine Research

Projectnummer WOT-04-009-035.04

Wettelijke Onderzoekstaken Natuur \& Milieu

Wageningen, augustus 2020

WOt-technical report 183

Sovon-rapport 2020/26

WMR-rapport C069/20

ISSN 2352-2739

DOI $10.18174 / 523041$ 


\section{Referaat}

Koffijberg K., P. de Boer, S.C.V. Geelhoed, J. Nienhuis, K. Oosterbeek, J. Postma (2020). Broedsucces van kustbroedvogels in de Waddenzee in 2018. Wettelijke Onderzoekstaken Natuur \& Milieu, WOt-technical report 183, Sovon-rapport 2020/26, Wageningen Marine Research-rapport C069/20, 42 blz; 11 figs; 8 tab; 39 refs.

Sinds 2005 worden in de Waddenzee jaarlijks gegevens verzameld over het broedsucces van een aantal karakteristieke kustbroedvogels. Tien vogelsoorten worden gevolgd die in trilateraal verband representatief worden geacht voor specifieke habitats en voedselgroepen. Het reproductiemeetnet kustbroedvogels wordt uitgevoerd als een 'early warning' systeem om het reproducerend vermogen van de vogelpopulaties in de Waddenzee te volgen en de achterliggende processen van populatieveranderingen te doorgronden. Het fungeert als een belangrijke aanvulling op de monitoring van aantallen en aantalsveranderingen en wordt uitgevoerd in het kader van trilaterale afspraken met Duitsland en Denemarken (TMAP). Tevens worden de gegevens opgenomen in de biodiversiteitsindicator B3 van OSPAR, t.b.v. de Kaderrichtlijn Marien. Uit de resultaten van 2018 blijkt dat de in eerdere jaren geschetste situatie met betrekking tot slechte broedresultaten weinig is veranderd, al zijn er lokaal en bij sommige soorten positieve uitzonderingen, mede in relatie tot speciale inrichtingsmaatregelen.

Trefwoorden: broedsucces, Waddenzee, Trilaterale monitoring, TMAP, Lepelaar, Eider, Scholekster, Kluut, Kokmeeuw, Kleine Mantelmeeuw, Zilvermeeuw, Grote Stern, Visdief, Noordse Stern

\section{Abstract}

Koffijberg K., P. de Boer, S.C.V. Geelhoed, J. Nienhuis, K. Oosterbeek, J. Postma (2020). Breeding success of coastal breeding birds in the Wadden Sea in 2018. Statutory Research Tasks Unit for Nature \& the Environment, WOt Technical Report 183, Sovon Report 2020/26, Wageningen Marine Research Report C069/20, 42 pp; 11 figs; 8 tabs.; 39 refs.

Data have been collected on the breeding success of several characteristic coastal breeding bird species in the Wadden Sea each year since 2015. Ten bird species considered representative of specific habitats and food groups are being monitored in a trilateral context. The monitoring scheme on breeding success in coastal breeding birds is run as an 'early warning system' to follow the reproductive capacity of the bird populations in the Wadden Sea and understand the processes underlying fluctuations in populations. It is a valuable addition to the monitoring of population numbers and is carried out under a trilateral agreement with Germany and Denmark (TMAP). The data are also included in the OSPAR biodiversity indicator B3 under the Marine Strategy Framework Directive. The 2018 results indicate that little has changed in the poor breeding success observed in previous years, although there were some positive exceptions locally and for some species, partly related to special conservation measures.

Keywords: breeding success, Wadden Sea, trilateral monitoring, TMAP, Eurasian Spoonbill, Common Eider, Eurasian Oystercatcher, Pied Avocet, Black-headed Gull, Lesser Black-backed Gull, Herring Gull, Sandwich Tern, Common Tern, Arctic Tern

Foto omslag: Steve Geelhoed

\section{(c) 2020 SovON Vogelonderzoek Nederland}

Postbus 6521, 6503 GA Nijmegen

Tel. (024) 7410 410;

e-mail: kees.koffijberg@sovon.nl

\author{
Wageningen Marine Research \\ Postbus 57, 1780 AB Den Helder \\ Tel. (0317) 480900 \\ e-mail: steve.geelhoed@wur.nl
}

Wettelijke Onderzoekstaken Natuur \& Milieu (unit binnen de rechtspersoon Stichting Wageningen Research), Postbus 47, 6700 AA Wageningen, T 03174854 71, info.wnm@wur.nl, www.wur.nl/wotnatuurenmilieu.

WOT Natuur \& Milieu is onderdeel van Wageningen University \& Research.

Dit rapport is gratis te downloaden van https://doi.org/10.18174/523041 of op www.wur.nl/wotnatuurenmilieu. De WOT Natuur \& Milieu verstrekt geen gedrukte exemplaren van rapporten.

- Overname, verveelvoudiging of openbaarmaking van deze uitgave is toegestaan mits met duidelijke bronvermelding.

- Overname, verveelvoudiging of openbaarmaking is niet toegestaan voor commerciële doeleinden en/of geldelijk gewin.

- Overname, verveelvoudiging of openbaarmaking is niet toegestaan voor die gedeelten van deze uitgave waarvan duidelijk is dat de auteursrechten liggen bij derden en/of zijn voorbehouden.

Wettelijke Onderzoekstaken Natuur \& Milieu aanvaardt geen aansprakelijkheid voor eventuele schade voortvloeiend uit het gebruik van de resultaten van dit onderzoek of de toepassing van de adviezen. 


\section{Woord vooraf}

In het voorliggende WOt-technical report worden de resultaten van het reproductiemeetnet kustbroedvogels in 2018 gepubliceerd. Doel is om de verzamelde gegevens te presenteren en toegankelijk te maken voor breder gebruik. Het project 'Reproductiemeetnet Kustbroedvogels' wordt uitgevoerd in het kader van de wettelijke onderzoekstaken binnen het thema Informatievoorziening Natuur, gecoördineerd door het ministerie van Landbouw, Natuur en Voedselkwaliteit, en is onderdeel van het trilaterale monitoring programma TMAP. Het hiervoor benodigde veldwerk wordt gecoördineerd door Sovon Vogelonderzoek Nederland, in samenwerking met Wageningen Marine Research. Het onderzoek zou zonder de inzet van veel vrijwilligers van Sovon niet kunnen worden uitgevoerd.

Kees Koffijberg, Peter de Boer, Steve Geelhoed, Jeroen Nienhuis, Kees Oosterbeek en Jelle Postma 



\section{Inhoud}

Woord vooraf

Summary

$1 \quad$ Inleiding

2 Methode en materiaal

2.1 Opzet van het Meetnet Reproductie in de Waddenzee $\quad 15$

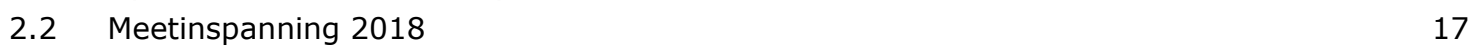

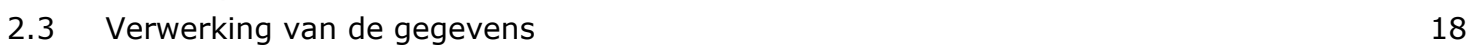

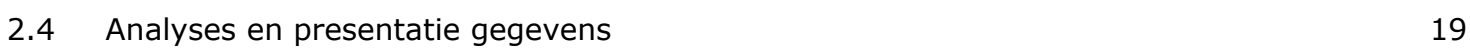

$\begin{array}{lll}2.5 & \text { Omstandigheden in } 2018 & 19\end{array}$

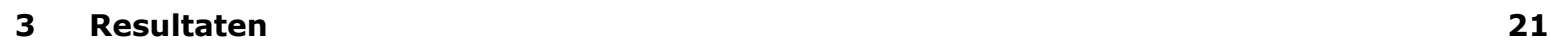

$\begin{array}{llr}3.1 & \text { Algemeen } & 21\end{array}$

$\begin{array}{ll}3.2 & \text { Lepelaar Platalea leucorodia - Eurasian Spoonbill } \\ 3.3 & 21\end{array}$

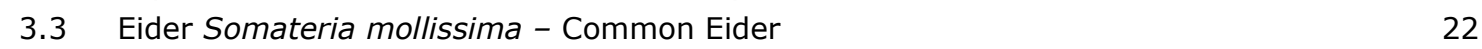

$\begin{array}{lll}3.4 & \text { Scholekster Haematopus ostralegus - Eurasian Oystercatcher } & 23\end{array}$

$\begin{array}{lll}3.5 & \text { Kluut Recurvirostra avosetta - Pied Avocet } & 24\end{array}$

3.6 Kokmeeuw Chroicocephalus ridibundus - Black-headed Gull 26

3.7 Kleine Mantelmeeuw Larus fuscus - Lesser Black-backed Gull 27

$\begin{array}{lll}3.8 & \text { Zilvermeeuw Larus argentatus - Herring Gull } & 28\end{array}$

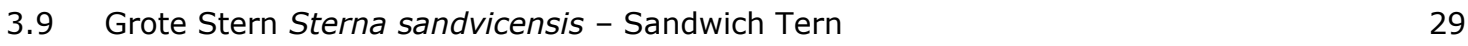

3.10 Visdief Sterna hirundo - Common Tern $\quad 30$

$\begin{array}{ll}3.11 & \text { Noordse Stern Sterna paradisaea - Arctic Tern } \\ \end{array}$

4 Conclusies en discussie $\quad 33$

$\begin{array}{lr}\text { Literatuur } & 35\end{array}$

$\begin{array}{ll}\text { Verantwoording en dankwoord } & 39\end{array}$ 



\section{Samenvatting}

In de Nederlandse Waddenzee werd in 2018 voor het $14^{\mathrm{e}}$ achtereenvolgende jaar op gecoördineerde en gestandaardiseerde wijze informatie verzameld over het broedsucces van een selectie van kustbroedvogels. Momenteel gaat het om tien verschillende soorten, die zowel in de Nederlandse Waddenzee als in de Duitse en Deense Waddenzee worden gevolgd (Trilateral Monitoring and Assessment Program, TMAP). Deze soorten zijn Lepelaar, Eider, Scholekster, Kluut, Kokmeeuw, Kleine Mantelmeeuw, Zilvermeeuw, Grote Stern, Visdief en Noordse Stern. Het Meetnet Reproductie in het Nederlandse deel van de Waddenzee is onderdeel van het WOt-IN (Wettelijke Onderzoekstaken Informatievoorziening Natuur) en wordt gecoördineerd door Sovon Vogelonderzoek Nederland in samenwerking met Wageningen Marine Research (WMR). De werkzaamheden in 2018 vonden tevens plaats als addendum op het Netwerk Ecologische Monitoring (NEM), en zijn in 2019 volledig in het NEM geïntegreerd. Belangrijkste doel is het verzamelen van gegevens over het broedsucces van kustbroedvogels, om daarmee zowel de "gezondheidstoestand" van vogelpopulaties in de Waddenzee in kaart te brengen, als de mogelijkheid te hebben vooruit te kijken naar toekomstige populatieontwikkelingen (early warning) en eventuele kansen voor herstel te verkennen. De meetinspanning in 2018 werd gedragen door vrijwilligers, medewerkers van terreinbeheerders, medewerkers van verschillende instituten en medewerkers van Sovon. Er waren ruim 70 soortspecifieke locaties (soms in hetzelfde gebied) verspreid over de Waddenzee waar informatie werd verzameld over het nestsucces (aantal succesvol uitgekomen legsels) en/of het uiteindelijke aantal vliegvlugge jongen per paar (hier verder broedsucces genoemd).

Eerdere analyses in het kader van het Meetnet Reproductie en daaruit voortvloeiende rapportages toonden aan dat het uitblijven van goede broedresultaten bij een hele serie soorten een sturende factor is bij de krimpende populaties kustbroedvogels in de Waddenzee. De gegevens die in 2018 werden verzameld duiden niet op een grote verandering in deze situatie. Vooral van Scholekster, Kluut, Kokmeeuw, Kleine Mantelmeeuw, Zilvermeeuw, Visdief en Noordse Stern wijzen de resultaten uit 2018 erop dat er in de breedte te weinig jongen vliegvlug worden. Bij Kleine Mantelmeeuw behoorden de broedprestaties zelfs tot de slechtste in de reeks tot nu toe. Bij een aantal soorten waren de bevindingen minder negatief; Lepelaar (steekproef klein, maar gemiddeld redelijk tot goed resultaat), Eider (beter broedsucces dan voorgaande jaren, zowel in nestfase (Vlieland) als bij jongentelling, enkele belangrijke gebieden evenwel geen gegevens) en Grote Stern (wisselend beeld per locatie). Predatie en wegspoelen van legsels bij hoge tijen in mei en juni waren bij alle soorten belangrijke oorzaken van mislukken. Bij Kleine Mantelmeeuw leek de voedselsituatie ongunstig. Predatie vond zowel langs de vastelandskust plaats als op de eilanden, maar de aard van de predatoren verschilde (vasteland groter aandeel zoogdieren).

In enkele gevallen waren er soorten en locaties die duidelijk afweken van het algemene beeld. Zo zijn Scholeksters succesvoller in de polders op de Waddeneilanden (Ameland, Schiermonnikoog), waar deze soort ook in hoge dichtheden voorkomt. Het hoge nestsucces van Kluten op een broedeiland in een kleiput op de Dollardkwelder (niet toegankelijk voor landpredatoren) contrasteerde sterk met nesten op de reguliere kwelder ernaast (onbeschermd), die vrijwel zonder uitzondering mislukten. Waarschijnlijk door toedoen van hoge vloeden in de kuikenperiode, bleef het uiteindelijke broedsucces evenwel ver onder de maat. Het gebruik van elektrische rasters bleek bij deze soort eerder ook succesvol, maar ervaringen in de Klutenplas in Noord-Groningen laten zien dat predatoren na verloop van tijd dergelijke rasters weten te passeren, en alsnog in staat zijn om alle nesten te prederen en/of de vestiging te verstoren. Rasters bleken ook succesvol tegen predatie bij Oterdum in de haven van Delfzijl (Kokmeeuw en Visdief), terwijl ze op de Punt van Reide niet afdoende waren en er net als in de Klutenplas toch predatie plaatsvond. Een in 2018 aangelegd broedeiland ("Stern") dat speciaal voor Visdief en Noordse Stern in de Eems ten zuiden van de Eemshaven werd ingericht kende direct in het eerste jaar succesvolle vestigingen van beide soorten. Niet alleen waren legsels succesvol, ook het aantal uitgevlogen jongen was met 0,87 jong/paar (Noordse Stern) en 1,05 jong/paar (Visdief) beduidend groter dan elders in de Waddenzee. Of deze positieve uitzonderingen afdoende zijn om de vastgestelde afnames in aantallen tegen te gaan zal in de komende jaren moeten blijken. 



\section{Summary}

This report presents the results of the monitoring of breeding success in the Dutch Wadden Sea in 2018. This monitoring is carried out as part of a national surveillance scheme for coastal breeding birds and the trilateral TMAP programme in the Dutch, German and Danish Wadden Sea. It includes a selection of ten coastal breeding birds, at present Eurasian Spoonbill, Common Eider, Eurasian Oystercatcher, Pied Avocet, Black-headed Gull, Herring Gull, Lesser Black-backed Gull, Sandwich Tern, Common Tern and Arctic Tern. Data are collected both during the nesting phase (referred to as nest success) and during the chick-rearing phase (referred to as breeding success). The main aim is to determine breeding success in terms of the number of fledged chicks per pair. Data collection in 2018 was carried out at about 70 sites (a site is defined as a combination of species and site, see Table 2.3). During fieldwork in spring 2018 temperatures were mostly above average, but high tides in May and especially June (Figure 2.1) caused losses of nests and chicks at several sites.

Earlier analyses have shown that poor breeding success is one of the most important drivers for declining breeding numbers in several coastal breeding birds, both in the Dutch and in the German and Danish Wadden Sea. For the Dutch Wadden Sea, data collected in 2018 indicate very similar results to those in previous years. For Eurasian Oystercatcher, Pied Avocet, Black-headed Gull, Lesser Black-backed Gull, Herring Gull, Common Tern and Arctic Tern in particular, reproductive output across the entire Dutch Wadden Sea was low. Eurasian Spoonbill, Eider and Sandwich Tern fared better, Eider especially compared with previous years.

Reproductive output may be very different locally, causing a high level of variation in breeding success within the Wadden Sea. For instance, Eurasian Oystercatchers in the farmland polders on the Wadden Sea islands of Ameland and Schiermonnikoog perform much better than elsewhere, which is encouraging given the high breeding densities in those areas. A new breeding island in a clay pit on the salt marsh of the Dollard, which is inaccessible to ground predators because it is surrounded by water in which a fence has been erected, attracted large numbers of Pied Avocet. These nested highly successfully, compared with the nearly complete failure of nests outside the island in the surrounding salt marsh. Unfortunately, the final breeding success of the colony was very low, presumably because a series of high tides in the chick-rearing period reduced survival rates. Moreover, fencing may not guarantee successful breeding, as shown elsewhere along the Groningen coast, where predators (at least Red Fox) were able to negotiate an electric fence and raided a colony. Similar situations were found at the Punt van Reide area in the Dollard (low success of colonies of Black-headed Gull and Common Tern, despite electrical 'sheep' fence). On the other hand, fencing in the Delfzijl Port area provided sufficient protection to enable Black-headed Gull and Common Tern to breed successfully.

A newly created breeding site in the Eems Estuary close to Eemshaven, which was established in spring 2018, attracted a large number of Common Tern and Arctic Tern. Breeding success was among the highest values in the entire Wadden Sea, showing again (cf. Pied Avocet in the Dollard) how wellprepared conservation measures may provide good breeding opportunities. However, it remains unclear to what extent such local successes benefit the Wadden Sea population as a whole. 



\section{$1 \quad$ Inleiding}

In de Nederlandse Waddenzee worden sinds 2004-05 (soms al langer) gegevens verzameld over het broedsucces van kustbroedvogels, naast de al veel langer lopende monitoring van aantallen en verspreiding van kustbroedvogels (Koffijberg et al. 2015a, Boele et al. 2020). De monitoring van het broedsucces vindt plaats in het kader van het WOT-IN (Wettelijke Onderzoekstaken Informatievoorziening Natuur) en (sinds 2010) in het kader van het trilaterale TMAP-programma (Thorup \& Koffijberg 2015). De uitvoering in 2018 werd als aanvullende module aan het Netwerk Ecologische Monitoring gekoppeld. De broedsuccesgegevens van de Waddenzee leveren verder input voor de biodiversiteitsindicatoren voor de Kaderrichtlijn Marien (https://oap.ospar.org/en/osparassessments/intermediate-assessment-2017/) en voor een in samenwerking met het CBS in ontwikkeling zijnde indicator "broedsucces kustbroedvogels". Uitvoering van het Meetnet Reproductie Waddenzee is in handen van Wageningen Marine Research (WMR) en Sovon Vogelonderzoek Nederland.

Het broedsucces is naast de jaarlijkse overleving één van de belangrijkste parameters die de demografie van kustbroedvogels in de Waddenzee beschrijft (Van der Jeugd et al. 2014).

Kustbroedvogels zijn doorgaans langlevende soorten, zodat informatie over broedsucces een sterk signaal is of de betreffende soorten zich in een gezonde toestand bevinden. Kennis over de jaarlijkse variatie in broedresultaten is dus van belang als een 'early warning' systeem om het reproducerend vermogen van de vogelpopulaties in de Waddenzee te volgen, analoog aan het principe van het "toekomstperspectief" zoals dat in de Vogelrichtlijn wordt verwoord (CBS 2013). Informatie over broedsucces geeft inzicht in de achtergronden voor aantalsveranderingen en een snellere indicatie waar eventueel beleidsmaatregelen zijn te nemen om een (verwachte) negatieve aantalstrend een halt toe te roepen. Resultaten van het Meetnet Reproductie speelden dan ook een belangrijke rol in plannen om de broedmogelijkheden voor kustbroedvogels te verbeteren, zowel in trilateraal verband (Koffijberg et al. 2016a) als specifiek voor de Nederlandse Waddenzee (PRW 2018). Bij de maatregelen die momenteel op stapel staan in het kader van het Waddenfonds-project "Wij en wadvogels" speelt (verbeteren van) broedsucces eveneens een belangrijke rol.

Bij de opzet van het meetnet werden de concrete doelstellingen geformuleerd:

- Vaststellen van het reproducerend vermogen van broedvogelpopulaties in de Waddenzee;

- Jaarlijkse monitoring van het broedsucces bij een selectie van soorten in representatieve steekproefgebieden verspreid over de Waddenzee.

Er worden tien soorten broedvogels gevolgd (zie Tabel 2.2), ieder representatief geacht voor een bepaalde voedselgroep (scheldiereters, wormeneters, gemengd dieet) of een bepaald habitat (duinen, kwelders, binnendijkse broedplaatsen), en daarbij anticiperend op de praktische inpasbaarheid van het veldwerk voor de metingen (om die laatste reden is de Tureluur niet in het meetnet opgenomen, omdat het verzamelen van de benodigde gegevens in het veld erg tijdrovends is). De selectie is bepaald in trilateraal overleg met TMAP-partners uit Duitsland en Denemarken. De tien soorten worden vanaf 2010 gemonitord, maar bij een aantal ervan worden in de Nederlandse Waddenzee al vanaf 2004-2005 (soms langer) gegevens verzameld (Oosterhuis et al. 2004, Willems et al. 2005).

In de toekomst is het de bedoeling om alle gegevens van kustbroedvogels die in Nederland worden verzameld (bijv. in het Deltagebied, Lilipaly et al. 2019) in één database onder te brengen, zodat o.a. internationale conventies als OSPAR en de Kaderrichtlijn Marien beter kunnen worden bediend en de Nederlandse input voor de OSPAR-biodiversiteitsindicator robuuster (want meer geografische spreiding van gebieden) vormgegeven kan worden.

Het voorliggende rapport presenteert de resultaten van de broedsucces-monitoring in de Waddenzee in 2018. De opzet van het rapport is basaal van karakter. Belangrijkste doel is het toegankelijk maken van de monitoringgegevens voor verder gebruik. Dit rapport volgt op rapportages over eerdere jaren 
(Willems et al. 2005, De Boer et al. 2007, Van Kleunen et al. 2010, Van Kleunen et al. 2012, Koffijberg \& Smit 2013, Koffijberg et al. 2015b, Koffijberg et al. 2016b, Koffijberg et al. 2017, Koffijberg et al. 2018). 


\section{$2 \quad$ Methode en materiaal}

\subsection{Opzet van het Meetnet Reproductie in de Waddenzee}

Het Meetnet Reproductie in de Waddenzee richt zich primair op het verkrijgen van informatie over het aantal vliegvlugge jongen dat jaarlijks per paar wordt geproduceerd (hierna verder broedsucces genoemd, zie box aan eind van dit hoofdstuk voor de definitie). Het broedsucces is een belangrijke parameter die ook voor zogenaamde integratieve populatiemonitoring wordt gebruikt, omdat het in combinatie met de jaarlijkse overleving het belangrijkste mechanisme achter aantalsveranderingen in populaties vormt (Reneerkens et al. 2005, Van der Jeugd et al. 2014, Schekkerman et al. 2017). Inzicht in broedsucces biedt dus aanknopingspunten voor de vraag waarom bepaalde aantalsveranderingen optreden, en dat inzicht wordt groter indien ook de jaarlijkse overleving van broedvogels in de analyses wordt meegenomen (Van der Jeugd et al. 2014). Vanwege het langlevende karakter van veel soorten vormt informatie over het broedsucces een belangrijk eerste signaal waar populaties kustbroedvogels problemen ondervinden. Doordat we met langlevende soorten te maken hebben, zal verandering in overleving doorgaans een zwakker signaal geven, maar overleving is wel belangrijk om effecten van (veranderingen in) broedsucces goed te kunnen inschatten (Van der Jeugd et al. 2014, Schekkerman et al. 2017).

Het broedsucces is grotendeels het resultaat van een optelsom aan factoren die optreden tussen de start van een legsel en het uitvliegen van de jongen. Maar ook voorafgaand aan het broeden speelt o.a. de conditie van de oudervogels een rol, deze kan verlaagd zijn door bijv. voedselschaarste voorafgaand aan het broedseizoen (zogenaamde carry-over effecten, bijv. Duriez et al. 2012). Factoren die van belang kunnen zijn tijdens de eifase zijn o.a. predatie of hoge vloeden en tijdens de jongenfase bijv. conditie (voedselschaarste) of slecht weer (o.a. onderkoeling kuikens). Voorafgaand aan het broedseizoen kan de (slechte) conditie van de volwassen vogels doorwerken in de broedresultaten.

Om te weten te komen in welk stadium van het broedproces de belangrijkste beperkingen liggen worden daarom naast het uiteindelijke broedsucces ook zoveel mogelijk gegevens verzameld in de nest- en kuikenfase (zie Tabel 2.1 voor een overzicht van verzamelde parameters). Inzicht in het slagen of mislukken van legsels (nestsucces), het uiteindelijke broedsucces en de achterliggende oorzaken bieden aanknopingspunten welke van de factoren in tabel 2.1 van belang zijn. Voor het volgen van nesten wordt aangesloten bij het Meetnet Nestkaarten van Sovon Vogelonderzoek Nederland, zoals dat wordt uitgevoerd in het kader van het Netwerk Ecologische Monitoring (Van Turnhout 2008). Door de combinatie van het Meetnet Nestkaarten en het Meetnet Reproductie in de Waddenzee kan op efficiënte wijze het broedsucces van kustbroedvogels in de Waddenzee in kaart worden gebracht. De kadertekst op de volgende pagina beschrijft welke definities we hanteren voor nestsucces en broedsucces.

Welke gegevens in het veld worden verzameld is afhankelijk van de soort. Voor in kolonies broedende soorten (meeuwen en sterns) kan het gehele broedproces met de juiste technieken goed worden gevolgd. Bij meer verspreid of verborgen broedende soorten (bijv. Eider) wordt het volgen in de eifase lastiger, mede ook vanuit oogpunt van verstoring. Kluten daarentegen gaan na het uitkomen van de eieren met hun jongen weg uit de buurt van het nest, en zijn juist in de kuikenfase veel moeilijker te volgen. De gebruikte werkwijze in het veld moet dus worden afgestemd op het gedrag van de tien meetsoorten en is soms een compromis tussen informatiebehoefte, verstoringsrisico en praktische haalbaarheid, zie verder paragraaf 2.2 voor details.

De in tabel 2.1 genoemde factoren die het broedsucces potentieel beïnvloeden, kunnen binnen de Waddenzee sterk variëren. Zo is bijv. het risico van predatie langs de vastelandskust doorgaans groter dan op de eilanden, waar de grotere landpredatoren als Vos en marterachtigen ontbreken. Ook is de voedselsituatie niet in de hele Waddenzee gelijk. Voor een representatief overzicht van het 
broedsucces is het dus van belang om gegevens uit verschillende delen van de Waddenzee te verzamelen. Om een goede spreiding in habitats en ligging van locaties te verkrijgen wordt er in het reproductiemeetnet naar gestreefd om voldoende stratificatie van meetpunten te hebben over gebieden en habitats (zie paragraaf 2.2).

Tabel 2.1 Overzicht van verzamelde parameters in het Meetnet Reproductie (en Meetnet Nestkaarten) in de Waddenzee, onderscheiden naar eifase en kuikenfase. Tevens zijn de belangrijkste factoren samengevat die de uitkomst van deze parameters kunnen beïnvloeden en/of welke indicatorwaarde de resultaten hebben. Het overzicht geeft een algemeen beeld en kan in detail afwijken, afhankelijk van de soort. Parameters recorded for monitoring breeding success of coastal breeding birds in the Dutch Wadden Sea, including their indicator value.

\begin{tabular}{|c|c|c|c|}
\hline Parameter & Eifase & Kuikenfase & Factoren van invloed / indicator voor \\
\hline Legselgrootte & $x$ & & Conditie ouders \\
\hline Legbegin (datum eerste ei) & $x$ & & $\begin{array}{ll}\text { - } & \text { conditie ouders } \\
\text { - } & \text { voedselsituatie ter plaatse } \\
\text { - } & \text { habitat (groei vegetatie) } \\
\text { - } \quad \text { weersomstandigheden (temperatuur) }\end{array}$ \\
\hline Vervolg- en tweede legsels & $x$ & & $\begin{array}{ll}\text { - } & \text { conditie ouders } \\
\text { - } & \text { predatie } \\
\text { - } & \text { risico overstroming bij stormvloed } \\
\text { - } & \text { risico vertrapping bij begrazing } \\
\text { - } & \text { belasting met contaminanten }\end{array}$ \\
\hline Groei (conditie) kuikens & & $x$ & $\begin{array}{l}\text { - } \quad \text { voedselsituatie ter plaatse } \\
\text { - } \quad \text { weersomstandigheden }\end{array}$ \\
\hline Overleving jongen & & $x$ & $\begin{array}{ll}\text { - } & \text { voedselsituatie ter plaatse } \\
\text { - } \quad \text { predatie } \\
\text { - } \quad \text { weersomstandigheden (temperatuur, } \\
\text { neerslag en optreden stormvloed) }\end{array}$ \\
\hline $\begin{array}{l}\text { Uitvliegsucces (jongen per paar, hier } \\
\text { verder als broedsucces gedefineerd) }\end{array}$ & & $x$ & $\begin{array}{ll}\text { - } & \text { voedselsituatie ter plaatse } \\
\text { - } \quad \text { predatie } \\
\text { - } \quad \text { weersomstandigheden }\end{array}$ \\
\hline
\end{tabular}

\section{Definities nestsucces en broedsucces}

Dit rapport gaat over het broedsucces van kustbroedvogels in de Waddenzee. De term broedsucces heeft hier exclusief betrekking op het uiteindelijk aantal vliegvlugge jongen per paar (in de gemeten steekproef, of in het hele telgebied, indien in het hele telgebied broedsucces werd gemeten). Het succesvol uitkomen van legsels, elders ook broedsucces genoemd, wordt in dit rapport consequent als nestsucces gedefinieerd. Dit nestsucces kan, al naar gelang de beschikbaarheid van de gegevens, op twee manieren worden bepaald: (1) op de klassieke manier, als het percentage uitgekomen nesten en (2) als nestsucces $\mathrm{H}$, bepaald met de Mayfield methode. De Mayfield-methode gaat uit van de dagelijkse overlevingskansen van legsels, in combinatie met de ligduur van een legsel (Mayfield 1961, 1975, Beintema 1992). Mayfieldgetallen worden alleen opgenomen voor soorten waarvan nesten frequent werden gevolgd en gegevens werden ingevoerd in de Nestkaart-applicatie van Sovon. Voor het overige wordt het klassieke nestsucces gebruikt, dat als handicap heeft dat het nestsucces wordt overschat (Beintema 1992). Alleen in geval van nesten die intensief worden gevolgd, is het klassieke nestsucces vergelijkbaar met nestsucces zoals die uit Mayfield-berekeningen komt. In dit rapport wordt met name het nestsucces via de Mayfield-methode gepresenteerd, maar wordt in sommige gevallen ook klassiek nestsucces gebruikt als de gegevensverzameling bepaling via Mayfield belemmerde (welke methode werd gebruikt wordt altijd in de tekst aangegeven). 


\subsection{Meetinspanning 2018}

De coördinatie en de uitvoering van het veldwerk voor het reproductiemeetnet wordt uitgevoerd door Sovon Vogelonderzoek Nederland (grootste deel Waddengebied) en Wageningen Marine Research (intensieve populatiestudie Scholekster Texel). Voor de aansturing van het veldwerk werd geput uit de poule aan vrijwilligers, vogelwachters en andere medewerkers van terreinbeheerders, aangevuld met professionele inzet van veldmedewerkers van Sovon. Door de jaren heen gaat het om een betrekkelijk kleine groep deelnemers met veel expertise. In een aantal gevallen werden gegevens van andere projecten en initiatieven gebruikt, zoals de monitoring van sterns bij de Eemshaven (de Boer \& Koffijberg 2019), onderzoek aan Kleine Mantelmeeuwen in het kader van het Gemini-project op Schiermonnikoog en monitoring op de Dollardkwelder t.b.v. de dijkverbetering (Bos et al. 2018a,b). Gegevens van Lepelaars worden verzameld door de Werkgroep Lepelaar, die haar gegevens verzameld in het kader van het Metawad project. De vogelwachters van Griend en Rottumerplaat meten voor verschillende soorten het broedsucces (o.a. Lutterop \& Kasemir 2018). Gegevens van het onderzoek aan grote meeuwen in de Kelderhuispolder op Texel van het NIOZ (o.a. Camphuysen 2013) werden helaas niet beschikbaar gesteld voor het in dit rapport gepresenteerde overzicht.

Alle veldmedewerkers, voor zover aangestuurd door Sovon, werden voorzien van een instructie, afgeleid van de Engelstalige trilaterale handleiding voor het monitoren van broedsucces (Koffijberg et al. 2011). Op Texel werd voor Grote Stern gebruik gemaakt van een drone (Spaans et al. 2018). De uitvoering van het veldwerk verschilt per soort. Oosterhuis et al. (2004) en Koffijberg et al. (2011) geven een overzicht van de gangbare methodieken per soort en beschrijven de methodes in detail. Tabel 2.2 geeft op hoofdlijnen inzicht hoe de gegevens per soort werden verzameld. Richtlijnen voor het uitvoeren van nestonderzoek staan ook per soort online op https://www.sovon.nl/nl/content/vogelinfo, gebruik van nestkaarten t.b.v. het Meetnet Nestkaarten op https://www.sovon.nl/nl/onderzoek/nestonderzoek.

Tabel 2.2 Overzicht van de in deze studie gehanteerde methodes per soort (voor details zie Oosterhuis et al. 2004, Koffijberg et al. 2011). Overview of methods used during fieldwork in the monitoring scheme of breeding success of coastal breeding birds in the Dutch Wadden Sea.

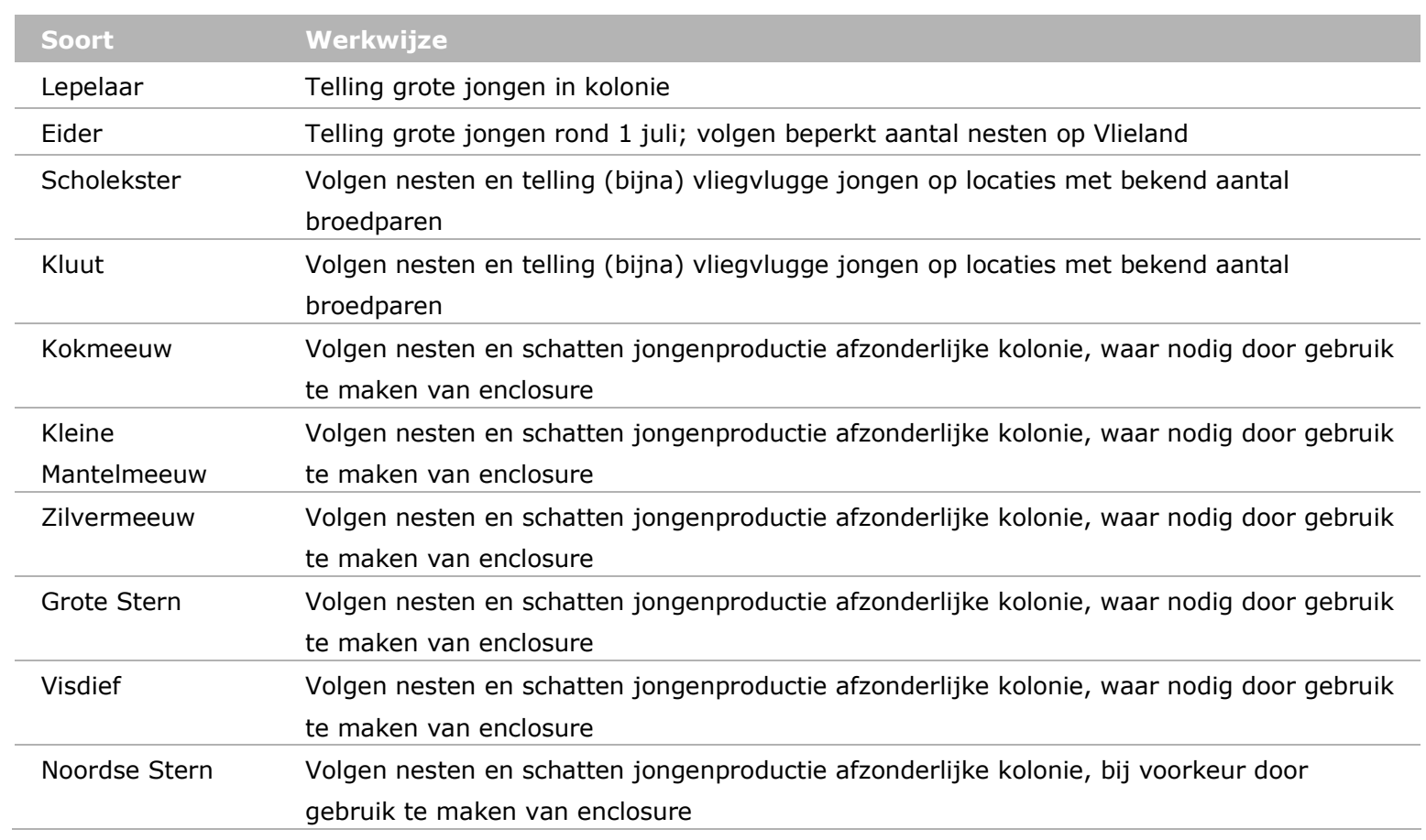

In het broedseizoen van 2018 werden in totaal voor 73 soort x gebiedscombinaties gegevens verzameld (Tabel 2.3), vergelijkbaar met 2017 (76). Eider, Scholekster, Kluut en Visdief werden het meest intensief en het meest verspreid over de Waddenzee onderzocht, zij het soms wel met kleine steekproeven of een beperkte geografische spreiding. In de meeste gevallen worden voor specifieke soorten jaarlijks dezelfde locaties gevolgd. Terschelling en de Friese Waddenkust zijn niet of 
nauwelijks vertegenwoordigd in het meetnet, ondanks gerichte pogingen om hier via de terreinbeheerder of vrijwilligers broedsucces-gegevens te verzamelen. Met name langs de Friese Waddenkust bevinden zich belangrijke kolonies van Kluut en Noordse Stern, waarvan gegevens zouden bijdragen aan de representativiteit van het meetnet. Dit is een belangrijk aandachtspunt bij de gegevensverzameling in de komende jaren.

Tabel 2.3. Overzicht van het in 2018 verzamelde materiaal van reproductiegegevens voor alle bestudeerde soorten (van gebieden tussen haakjes waren de gegevens voor gebruik in dit rapport nog niet beschikbaar). Weergegeven is het aantal gebieden/kolonies waar gegevens werden verzameld, gegroepeerd per regio. Overview of data collection in 2018. For each region, the number of sample sites is given (usually a colony or specific breeding site). Figures in brackets mean data was collected but not available yet for reporting.

\begin{tabular}{|c|c|c|c|c|c|c|c|c|c|c|}
\hline Regio / Gebied & $\frac{2}{\frac{10}{10}}$ & $\frac{\frac{1}{0}}{\frac{1}{0}}$ & $\begin{array}{l}\frac{1}{0} \\
\frac{0}{2} \\
\frac{0}{0} \\
\frac{0}{0} \\
\frac{5}{0} \\
0\end{array}$ & $\frac{}{3}$ & $\begin{array}{l}3 \\
\frac{3}{0} \\
\frac{0}{0} \\
\frac{0}{0} \\
\end{array}$ & 필 & $\begin{array}{l}3 \\
\frac{3}{d} \\
\frac{3}{2} \\
\frac{1}{2} \\
\end{array}$ & 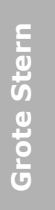 & 告 & $\frac{0}{\frac{0}{8}}$ \\
\hline \multicolumn{11}{|l|}{ Westelijke Waddenzee } \\
\hline Texel & - & 3 & 4 & 6 & 4 & - & - & 2 & 4 & 1 \\
\hline Balgzand & - & - & 1 & - & - & - & - & - & - & - \\
\hline Vlieland & 1 & 2 & 1 & - & - & 1 & 1 & - & 1 & 1 \\
\hline Griend & 1 & 1 & 1 & - & 1 & - & - & 1 & 1 & 1 \\
\hline \multicolumn{11}{|l|}{ Oostelijke Waddenzee } \\
\hline Terschelling & - & 1 & - & - & - & - & - & - & 1 & - \\
\hline Ameland & 1 & 1 & 1 & - & 1 & - & - & - & - & - \\
\hline Schiermonnikoog & 1 & 1 & 3 & - & - & 1 & 1 & - & 1 & - \\
\hline Rottumerplaat/-oog & $(1)$ & - & - & - & - & - & - & - & 1 & - \\
\hline Friese kust & - & - & - & - & - & - & - & - & - & - \\
\hline Noordkust Groningen & - & 1 & 1 & 1 & - & - & - & - & - & - \\
\hline \multicolumn{11}{|l|}{ Eems-Dollard } \\
\hline Eemshaven & - & - & - & - & - & - & - & - & - & - \\
\hline Eems & - & - & - & - & - & - & - & - & 1 & 1 \\
\hline Havengebied Delfzijl & - & - & 1 & - & 2 & - & - & - & 2 & 1 \\
\hline Punt van Reide & - & - & - & - & 1 & - & - & - & 1 & 1 \\
\hline Dollard & - & - & - & 3 & - & - & - & - & - & - \\
\hline Alle gebieden & 5 & 10 & 13 & 10 & 9 & 2 & 2 & 3 & 13 & 6 \\
\hline
\end{tabular}

\subsection{Verwerking van de gegevens}

Gegevens over de lotgevallen van nesten werden verwerkt via het Meetnet Nestkaarten van Sovon/CBS. Dit project is onderdeel van het Netwerk Ecologische Monitoring en heeft o.a. tot doel nestsucces/broedsucces vast te leggen en verschuivingen in het begin van de eileg te volgen, als graadmeter voor klimaatveranderingen (zie van Turnhout 2008). Invoer van de veldgegevens gebeurt met de speciale software "Nestkaart" (zie bijlage 4 in Willems et al. 2005), en verloopt geheel digitaal. De ingevoerde gegevens zijn vervolgens gekoppeld aan de database van het Meetnet Reproductie. Deze database is online toegankelijk voor de waarnemers. In deze database is informatie over de locatie, soort, (globale) lotgevallen van legsels, lotgevallen van kuikens, het aantal uitgevlogen jongen per paar en eventuele aanvullende opmerkingen opgeslagen. Voor de analyse worden beide databases 
uitgelezen en gecontroleerd op onwaarschijnlijkheden en eventuele dubbele records. Uit de definitieve output werden de tabellen voor deze rapportage gegenereerd. In geval van twijfel over de kwaliteit van de gegevens, of in geval van sommige hele kleine steekproeven, werden de gegevens niet meegenomen in de bespreking van de resultaten.

\subsection{Analyses en presentatie gegevens}

Uit de verzamelde gegevens zijn primair twee belangrijke parameters geanalyseerd, te weten het nestsucces (uitkomstsucces) en het broedsucces (het aantal vliegvlugge jongen per broedpaar). Het nestsucces wordt in dit rapport zoveel mogelijk gebaseerd op analyses met de Mayfield-methode (Beintema 1992); alleen bij kleine steekproeven wordt teruggegrepen op het klassieke nestsucces, ofwel de verhouding succesvolle/niet-succesvolle nesten. Dit is ook het geval als de meeste gegevens betrekking hebben op klassieke nestgegevens (Scholekster). Klassieke nestcijfers neigen in de meeste situaties (tenzij er vrijwel dagelijks een controle plaatsvindt) tot een overschatting van het broedsucces (Beintema 1992). Mayfield gaat uit van een dagelijkse overlevingskans $p$ : de kans dat een nest dat vandaag wordt gevonden er ook morgen nog ligt. Door deze kansen te bepalen over de hele eifase ('ligduur') wordt het uitkomstsucces $H$ berekend (zie Willems et al. 2005 voor verdere details). Welke methode werd gebruikt wordt steeds in de tekst genoemd.

Het uiteindelijke aantal vliegvlugge jongen per paar werd berekend door het aantal (bijna) vliegvlugge jongen te delen door het vastgestelde aantal broedparen, hetzij in de steekproef waar broedsucces werd gemonitord, hetzij in het hele telgebied, of in de hele kolonie. Bij Eidereend wordt het aantal jongen zelfs bepaald voor een heel eiland, omdat bij de jongentelling in het eind van het broedseizoen geen onderscheid naar deelgebieden is te maken. Voor Eider en Kluut worden speciale jongentellingen georganiseerd, voor de in kolonies broedende meeuwen en sterns wordt dit deels door middel van enclosures, en deels door middel van vangst-terugvangst methodieken bepaald (zie Koffijberg et al. 2011 voor details). Voor Scholekster werden in een klein aantal plots voor het Broedvogel Monitoring Project (BMP, t.b.v. de reguliere broedvogelinventarisaties) begin juli een jongentelling uitgevoerd. In sommige gevallen was alleen een schatting mogelijk van het aantal uitgevlogen jongen.

\subsection{Omstandigheden in 2018}

Na een zachte december en januari kende 2018 een koude start in februari en maart (https://www.knmi.nl/). Van april tot en met juli, de periode dat kustbroedvogels hun broedseizoen hebben, was het evenwel aan de warme en droge kant. De temperaturen lagen in deze hele periode boven het langjarige gemiddelde. Mei tot en met juli waren bovendien extreem droog, met bovengemiddelde hoeveelheden zon in mei en juli. Qua weersomstandigheden waren de nestomstandigheden en opgroeimogelijkheden voor kuikens dus goed (los van eventuele veranderingen in de voedselsituatie). Er waren echter wel meerdere dagen met hoog water in de Waddenzee (Figuur 2.1), o.a. in april (2), mei (4), juni (6) en juli (1). De negatieve gevolgen voor nesten en kuikens traden alleen lokaal op. Zo waren er problemen op Ameland op 15 juni, op Vlieland en op Rottumerplaat op 22 juni en in de Dollard op 19, 21 en 22 juni. Ook waren er meldingen van verliezen door slecht weer en stuivend zand in juni (Vlieland, Griend). In de soortteksten wordt hier verder op ingegaan. 


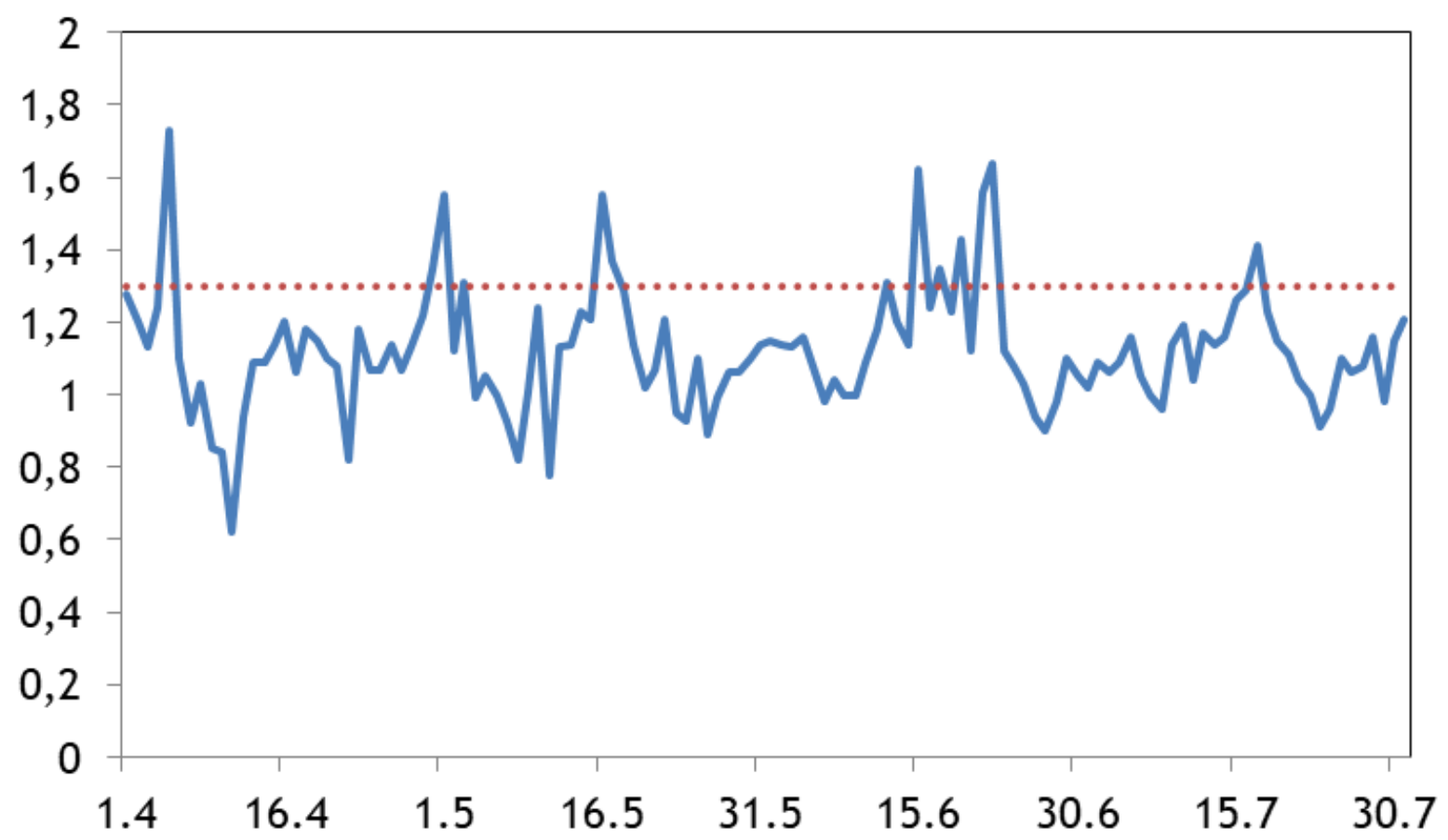

Figuur 2.1 Waterstanden bij Lauwersoog tussen 1 april en 31 juli 2018 (datums op x-as). De rode stippellijn geeft de hoogte van het tij aan waarbij ten minste lokaal buitendijkse gebieden te maken krijgen met overspoelingen. Vooral in mei-juni kunnen deze tot gevolg hebben dat nesten wegspoelen en/of kuikens verdrinken. Gegevens Rijkswaterstaat, waterinfo.rws.nl. Water levels at Lauwersoog between $1^{\text {st }}$ of april en $31^{\text {th }}$ of july 2018 (dates on x-axis). The red dotted line indicates the height of the tide at which at least some of het areas outside the dikes will experience flooding. Especially in May-June these floods can result in washing away of clutches and/or drowning of chicks. Source Rijkswaterstaat, waterinfo.rws.nl. 


\subsection{Algemeen}

In dit hoofdstuk worden de resultaten van de tien meetnetsoorten afzonderlijk besproken. Per soort wordt een beknopte beschrijving gegeven van het voorkomen en de trends in aantallen broedparen in de Waddenzee tot en met 2018. De aantallen en trends in aantallen zijn afgeleid van de broedvogeltellingen die in het kader van het Netwerk Ecologische Monitoring (Meetnet Broedvogels van Sovon/CBS) worden uitgevoerd en waarover tot en met 2018 is gerapporteerd (zie Boele et al. 2020). Trends in aantallen broedparen worden weergegeven als indexwaarde, afgezet tegen het eerste jaar van de reeks tellingen (1990). Deze aanpak houdt er rekening mee dat niet alle soorten jaarlijks integraal worden geteld (dus een optelsom van broedparen eerder de teldekking weergeeft), en gaten in de telreeksen worden bijgeschat met behulp van een vast gedefinieerde routine, zie verder Boele et al. 2020 voor wijze van berekening. Voor de relevante soorten wordt de huidige broedpopulatie afgezet tegen de instandhoudingsdoelstellingen zoals die in het Natura 2000beheerplan voor de Waddenzee worden genoemd (zie ook www.sovon.nl onder vogelinfo en gebieden). Doordat in 2018 een integrale broedvogeltelling werd uitgevoerd in het kader van de zesjaarlijkse cyclus van TMAP, weten we voor dit jaar ook de grootte van de broedpopulaties van soorten die niet jaarlijks integraal worden geteld, zoals Scholekster. Een samenvatting van de integrale telling in de Nederlandse Waddenzee is opgenomen in het broedvogelrapport 2018 van Sovon Vogelonderzoek Nederland (Boele et al. 2020).

Vervolgens presenteren we basale informatie over het broedsucces in 2018, zoals dat in het kader van het Meetnet Reproductie is verzameld. Eventueel worden beperkingen van de gegevens aangegeven (kleine steekproef). Voor het opstellen van de soortteksten is veel informatie ontleend aan eerder verschenen rapportages over het reproductiemeetnet Waddenzee (Willems et al. 2005, De Boer et al. 2007, Van Kleunen et al. 2010, 2012, Koffijberg et al. 2015b, Koffijberg et al. 2016a, Koffijberg et al. 2017, Koffijberg et al. 2018). Tevens is gebruik gemaakt van het internationale overzicht dat in het kader van TMAP werd gemaakt door Thorup \& Koffijberg (2015). Het aantal jongen dat nodig is om de populatie op z'n minst stabiel te houden is ontleend aan Koffijberg \& Smit (2013), zie ook Thorup \& Koffijberg (2015) voor aanvullingen. De vergelijking met instandhoudingsdoelstellingen die voor het Natura 2000-gebied Waddenzee en de duinen op de Waddeneilanden gelden zijn ontleend aan de vigerende Natura 2000-beheerplannen (https://www.bij12.nl/onderwerpen/natuur-enlandschap/natura-2000-beheerplannen/).

Specifieke bronnen in de tekst worden alleen genoemd als het om andere dan één van de bovenstaande publicaties gaat.

\subsection{Lepelaar Platalea leucorodia - Eurasian Spoonbill}

In 2018 broedde ruim de helft (52\%) van alle Nederlandse broedparen Lepelaars in de Waddenzee. De gemiddelde jaarlijkse groei in aantallen nam na 2007 ( $+1 \%)$ duidelijk af ten opzichte van de hele periode $(+8 \%)$ (Figuur 3.1), hetgeen past bij de beschrijving van dichtheidsafhankelijke processen door Lok et al. (2009, 2013) en Oudman et al. (2017), die nu werkzaam zijn op de waddenpopulatie en erop wijzen dat de draagkracht van de Waddenzee bereikt wordt. Het aantal broedparen was met 1712 paar in 2018 een fractie kleiner dan in 2017, maar ligt nog altijd ruim boven de geformuleerde instandhoudingsdoelstellingen voor de Waddenzee (en de duinen op de Waddeneilanden).

Broedsucces-gegevens werden verzameld op Vlieland, Griend, Ameland, Schiermonnikoog en Rottumerplaat, en waren vooralsnog alleen beschikbaar voor vier van deze locaties. Het aantal jongen per paar varieerde van 0,86 (Vlieland) tot 1,36 (Schiermonnikoog). Hoewel de steekproef klein is, 
suggereren deze cijfers een beter broedseizoen dan in 2017, maar liggen ze nog altijd beneden de waarden die tot 2005 gebruikelijk waren (doorgaans > 1,5 jong per paar). Op de lange termijn (zowel sinds 1992 als sinds de start van het meetnet in 2005) is in de Nederlandse Waddenzee sprake van een significante afname van het broedsucces (Figuur 4.2 in Koffijberg et al. 2017), waarschijnlijk voortvloeiend uit de bovenbeschreven draagkrachtbeperkingen. In die context valt ook de stagnerende groei van het aantal broedende Lepelaars in de Nederlandse Waddenzee op (Figuur 3.1).

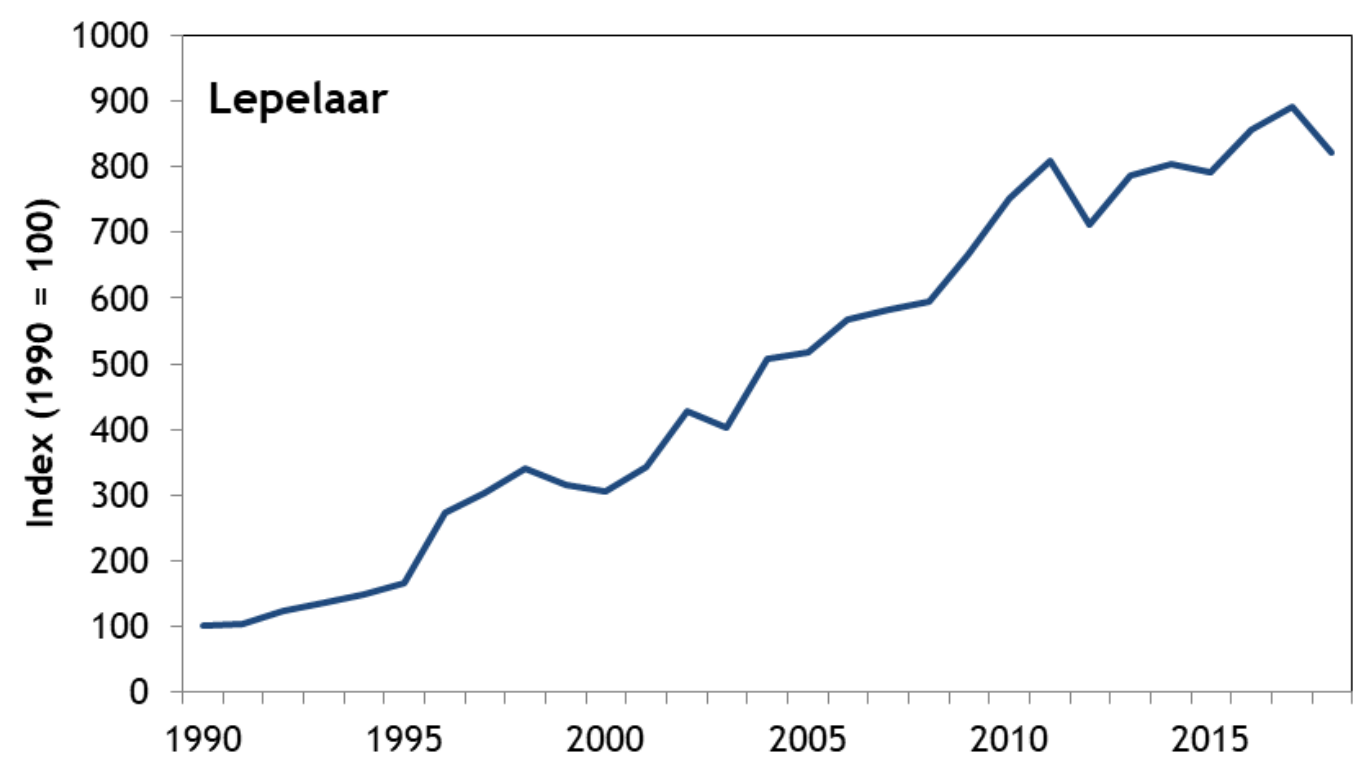

Figuur 3.1 Trend van Lepelaar als broedvogel in de Waddenzee (aantal broedparen op basis van integrale tellingen, als index weergegeven met basisjaar 1990). Gegevens broedvogelmeetnet Sovon/CBS. Trends in breeding Eurasian Spoonbill in the Dutch Wadden Sea (expressed as indices).

\subsection{Eider Somateria mollissima - Common Eider}

Eiders broeden in Nederland voornamelijk in de Waddenzee. In 2018 ging het om 3233 paar. Broedpopulaties in de Duitse en Deense Waddenzee zijn klein in vergelijking met die in Nederland. Vanaf de start van het broedvogelmeetnet in 1990 nam het aantal broedende Eiders in Nederland significant af (Figuur 3.2). Deze negatieve trend bedraagt zowel sinds de start van de reeks als over de laatste 12 jaar (sinds 2007) gemiddeld -3\% per jaar. Het verloop van het aantal broedparen in de Waddenzee kende in de afgelopen dertig jaar sterke schommelingen en periodiek massale sterfte, veroorzaakt door fluctuaties in het voedselaanbod (schelpdieren) en voedselschaarste (o.a.

Camphuysen et al. 2002, Kats 2007). Daarnaast kan een deel van de fluctuaties worden veroorzaakt door telproblemen op de Waddeneilanden. Het aantal broedvogels in de Waddenzee bereikte in geen enkel jaar van het broedvogelmeetnet in 1990-2018 de geformuleerde instandhoudingsdoelstelling in het Natura 2000-beheerplan voor de Waddenzee (5000 paar).

In de studiekolonies op Vlieland bedroeg het nestsucces (Mayfield) bij 38 gevolgde nesten 54,6\%. De twee deelgebieden Kroon's Polders en Meeuwenduinen onderscheidden zich daarbij nauwelijks (resp. 59,1 en 51,2\%, Tabel 3.1). Het nestsucces bereikte daarmee de hoogste waarde sinds 2014 (ter vergelijking, in 2017 bedroeg het 34,6\%).

Tabel 3.1. Nestsucces van Eider in de Waddenzee in 2018, bepaald door middel van de Mayfield methode. Weergegeven is de steekproef van gevolgde nesten, de dagelijke overlevingskans $(p)$ met standaarddeviatie (Sd) en het uiteindelijke nestsucces met spreiding. Nest record data and nest succes according to Mayfield method in Common Eider.

\begin{tabular}{lrlrlrl} 
Plaats & $\begin{array}{c}\text { Aantal } \\
\text { nesten }\end{array}$ & & Sd & $\begin{array}{l}\text { Nestsucces } \\
(\%)\end{array}$ & $\begin{array}{l}\text { Spreiding Min- } \\
\text { Max (\%) }\end{array}$ \\
Vlieland, Kroon's Polders & 20 & 0,983 & 0,008 & 59,1 & $35,2-98,5$ \\
\hline Vlieland, Meeuwenduinen & 18 & 0,978 & 0,008 & 51,2 & $31,0-83,7$ \\
\hline
\end{tabular}


Volledige jongentellingen werden uitgevoerd op vier eilanden (Texel verdeeld over drie deelgebieden) en in een gebied aan de Groninger kust. De uitkomsten varieerden van 0,56 jong/paar op Ameland en De Schorren op Texel tot 1,47 jong/paar op Schiermonnikoog. Het (ongewogen) gemiddelde van alle locaties bedroeg 1,10 jong/paar en is hoger dan alle voorgaande jaren in de reeks (zie Figuur 4.4 in Koffijberg et al. 2017). Over de voorgaande periode (vanaf 2005) kon weliswaar geen significante trend in broedsucces worden bepaald, maar was het (gewogen) gemiddelde van het aantal jongen/paar steevast aan de lage kant (namelijk maximaal 0,64 jong/paar) voor het instandhouden van de populatie. Of de resultaten van 2018 representatief zijn voor de hele Waddenzee is onduidelijk, omdat op een aantal andere broedlocaties geen goede jongentellingen konden worden gedaan, waaronder belangrijke broedplaatsen als de Boschplaat op Terschelling (vanwege beperkte capaciteit bij de terreinbeheerders ter plaatse om in het veldwerk te participeren).

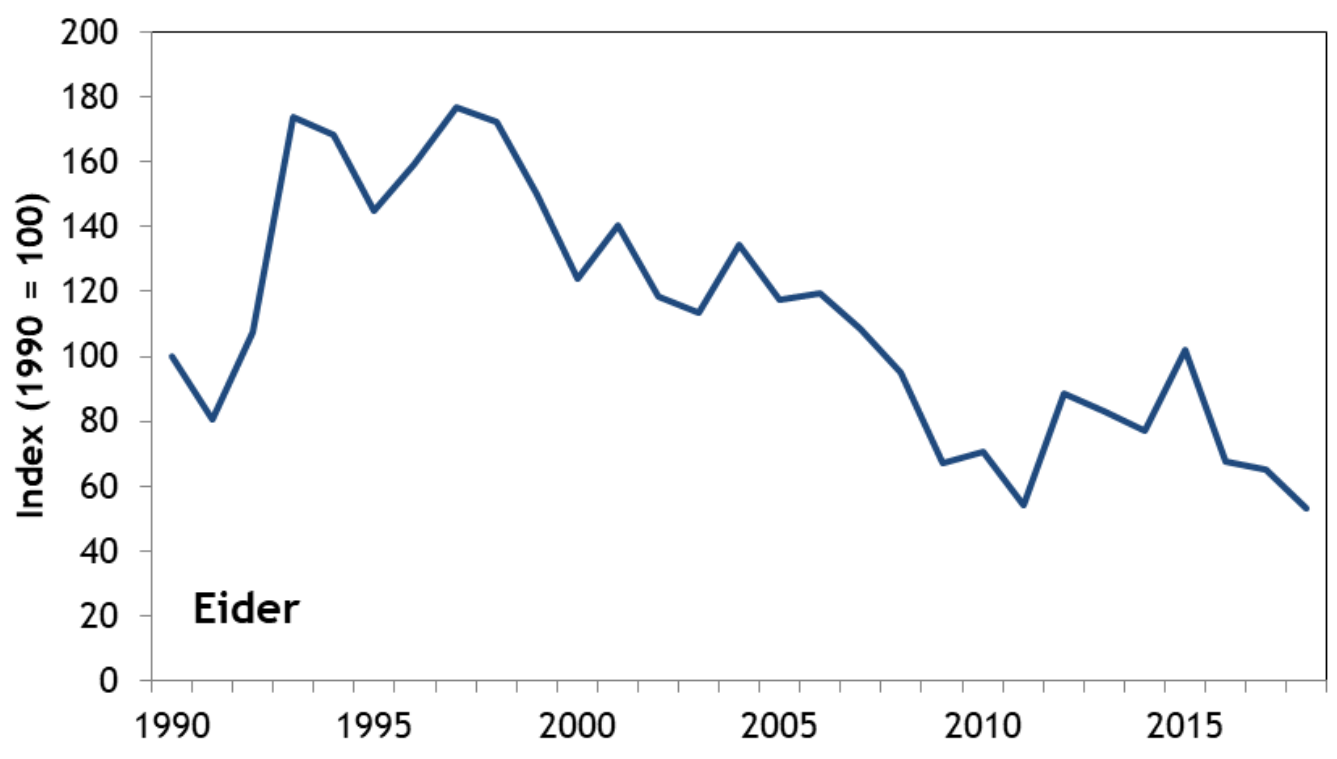

Figuur 3.2 Trend van Eider als broedvogel in de Waddenzee (aantal broedparen op grond van integrale tellingen, als index weergegeven met basisjaar 1990). Gegevens broedvogelmeetnet Sovon/CBS. Trends in breeding Common Eider in the Dutch Wadden Sea (expressed as indices).

\subsection{Scholekster Haematopus ostralegus - Eurasian Oystercatcher}

De Scholekster is één van de meest kenmerkende broedvogels in de Waddenzee. In 2018 broedden er ten minste 7605 paar (aantal zal iets onderschat zijn). De trend sinds 1990 vertoont een neergaande lijn, met een afname van gemiddeld $4 \%$ per jaar (analoog aan de landelijke afname) (Figuur 3.3). De oostelijke Waddenzee volgt deze afnemende trend ook na 2007, terwijl in de westelijke Waddenzee het aantal broedvogels recent (op een lager niveau) is gestabiliseerd. Het aantal Scholeksters in de Eems-Dollardregio is over de hele periode sinds 1991 stabieler, maar is gebaseerd op een kleine steekproef aan telgebieden (en een veel kleiner absoluut aantal broedparen). 


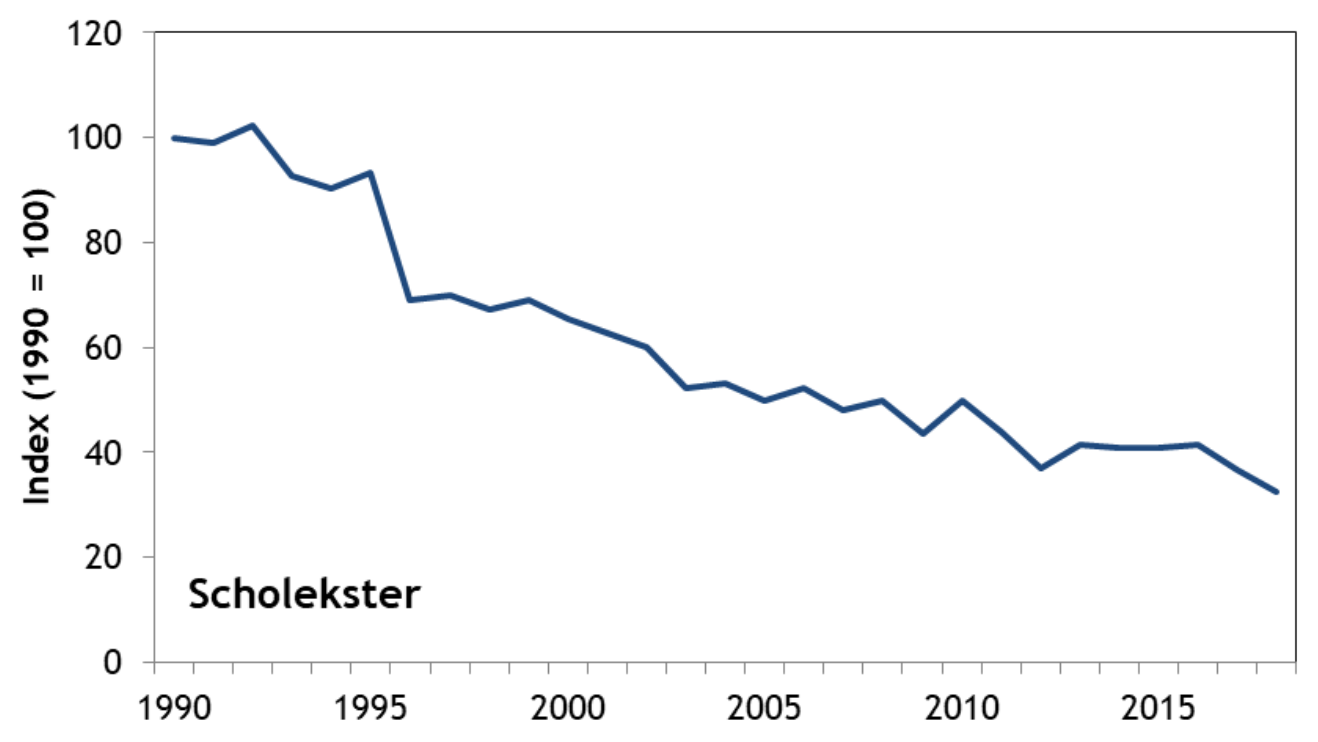

Figuur 3.3 Trend van Scholekster als broedvogel in de Waddenzee (aantal broedparen op grond van steekproeftellingen (BMP), als index geindexeerd op 1990). Gegevens broedvogelmeetnet Sovon/CBS. Trends in breeding Eurasian Oystercatcher in the Dutch Wadden Sea (expressed as indices).

Van vier locaties was informatie beschikbaar over het nestsucces (klassiek uitkomstpercentage). Dit was aan de lage kant op de Schermdijk van de Haven van Delfzijl (35,5\% bij 31 nesten) en op de hoge en lage kwelder van Schiermonnikoog (resp. 23,0 bij 39 nesten en 25,3\% bij 103 nesten). Uitschieter naar boven was de Buurdergrie op Ameland ( $91,5 \%$ bij 43 nesten). Dit laat zien dat er binnen de Waddenzee een grote variatie bestaat. Oorzaken van mislukken waren bij Delfzijl predatie en hoogtij, op Schiermonnikoog eveneens predatie (Bruine Kiekendief) en hoogtij.

Het aantal vliegvlugge jongen per paar werd op 11 locaties bepaald. Het bedroeg bij zes locaties minder dan 0,10 jong/paar. Op vier locaties varieerde het van 0,14 tot 0,33 jong per paar (Balgzand, Klutenplas in Noord-Groningen, Noordvlakduinen op Texel en Prins Hendrikpolder op Texel). Alleen in het oostelijk deel van de Banckspolder werden meer jongen grootgebracht: 0,46 jong/paar. Dit is het enige gebied in de steekproef waar voldoende jonge Scholeksters uitvlogen (ongeveer 0,35 jong/paar) om de jaarlijkse sterfte te compenseren. Het (ongewogen) gemiddelde van alle locaties komt op 0,16 jong/paar. Dit ligt nog duidelijk onder het niveau in 2017 (0,24 jong/paar) en past verder in de bandbreedte van broedsucces die in de voorgaande jaren werd vastgesteld (Figuur 4.6 in Koffijberg et al. 2017). Afgaande op het hoge nestsucces in de polder op Ameland en het hoge broedsucces in de Banckspolder op Schiermonnikoog lijken de polders op de Waddeneilanden duidelijk betere broedresultaten te halen dan andere gebieden binnen de Waddenzee. De oorzaken van het lage succes waren niet overal duidelijk: in zes gebieden werd predatie opgevoerd (Delfzijl, Klutenplas/Noord-Groningen, hoge en lage kwelder Schiermonnikoog, Noordvlakduinen/Texel, Balgzand).

\subsection{Kluut Recurvirostra avosetta - Pied Avocet}

In 2018 vestigden zich 1981 paar Kluten in de Waddenzee. Het grootste deel daarvan broedt langs de Fries-Groningse kust (incl. Dollard), deels ook in binnendijkse wetlands. De trend sinds 1990 is sterk negatief, met een gemiddelde jaarlijkse afname van 6\% per jaar (Figuur 3.4). Dit is vooral gevolg van een scherpe afname in de jaren na 2000. Voor de afgelopen 12 jaar (2007-2018) is de afname afgeremd (-2\% per jaar). In 2018 was er zelfs een lichte toename ten opzichte van 2017, maar het is te vroeg om dat als herstel te duiden. Het huidige aantal broedparen in de Waddenzee ligt ver onder de instandhoudingsdoelstellingen voor het Natura 2000-gebied Waddenzee (3800 paar). 


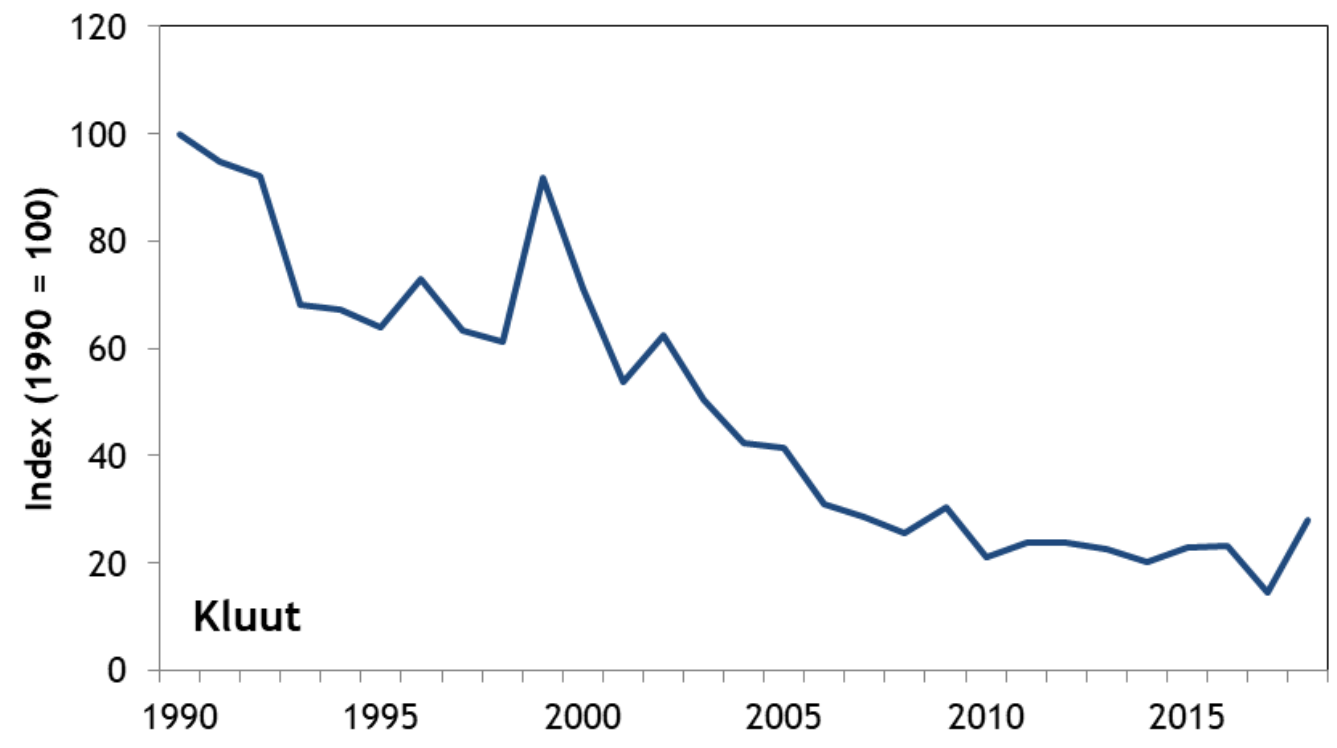

Figuur 3.4. Trend van Kluut als broedvogel in de Waddenzee (aantal broedparen op grond van integrale tellingen, als index weergegeven met basisjaar 1990). Gegevens broedvogelmeetnet Sovon/CBS. Trends in breeding Pied Avocet in the Dutch Wadden Sea (expressed as indices).

In twee gebieden werden nesten van Kluten gevolgd. In de Klutenplas die binnendijks in de LinthorstHomanpolder aan de Groninger kust ligt, en in de Dollard. In het eerste gebied mislukten alle 17 nesten door predatie (Vos), ondanks dat dit broedgebied door een elektrisch raster is omgeven om predatie door grondpredatoren tegen te gaan (De Boer 2019). Door het hoge predatierisico ging waarschijnlijk ook maar een klein aantal Kluten in dit gebied daadwerkelijk tot broeden over (De Boer 2019).

Tabel 3.2. Nestsucces van Kluut in de Dollard in 2018, bepaald door middel van de Mayfield methode (zie ook Bos et al. 2018b). Weergegeven is de steekproef van gevolgde nesten, de dagelijke overlevingskans $(p)$ met standaarddeviatie $(S d)$ en het uiteindelijke nestsucces met spreiding. Nest record data and nest succes according to Mayfield method in Pied Avocet.

\begin{tabular}{lrlllll} 
Plaats & $\begin{array}{c}\text { Aantal } \\
\text { nesten }\end{array}$ & & Sd & $\begin{array}{l}\text { Nestsucces } \\
(\%)\end{array}$ & $\begin{array}{l}\text { Spreiding Min- } \\
\text { Max }(\%)\end{array}$ \\
Kluteneiland Dollardkwelder & 39 & 0,996 & 0,002 & 90,6 & $79,1-100$ \\
\hline Kleirijperij (onbeschermd) & 6 & 0,882 & 0,045 & 3,0 & $0,2-43,6$ \\
\hline Kwelder-oost (onbeschermd) & 13 & 0,901 & 0,031 & 5,4 & $0,8-34,2$ \\
\hline
\end{tabular}

Op de Dollardkwelder werden op drie verschillende locaties metingen aan nesten gedaan: in een nieuwe grote kolonie op een net ingericht eiland op de kwelder (ook "Kluteneiland Dollard" genaamd, om verwarring met de "Klutenplas" in Noord-Groningen te vermijden), in een recent ingericht buitendijks kleidepot en op de oostelijke Dollardkwelder (Tabel 3.2, zie ook Bos et al. 2018b). Het nieuwe broedeiland is van een hekwerk in het water voorzien, zodat predatoren in eerste instantie moeite zullen hebben het eiland te bereiken. Het nestsucces (Mayfield) op het eiland was met 90,6\% erg hoog (Tabel 3.2). In de kleirijperij en op de oostelijke kwelder, beide onbeschermd tegen predatoren, was het nestsucces resp. 3,0 en 5,4\%, dus een fractie van dat op het beschermde broedeiland. Een dergelijk laag nestsucces werd ook in de meeste eerdere jaren op de Dollardkwelder gemeten: in de periode 2006-2017 was het broedsucces in 8 van de 11 jaren lager dan 10\%. Het hoge succes op het eiland maakt duidelijk wat effectieve maatregelen tegen predatie kunnen bewerkstelligen. Hogere nestsuccessen in situaties met beschermde maatregelen (elektrisch raster) werden ook in eerdere jaren vastgesteld (zie Koffijberg et al. 2017 voor overzicht), maar slechts éénmaal (Klutenplas Noord-Groningen in $2015,84,8 \%$ ) in de ordegrootte zoals nu op het nieuwe Kluteneiland op de Dollardkwelder werd gemeten. Het aantal jongen dat tijdens speciale jongentellingen in 2018 werd vastgesteld was evenwel met 0,03 jong/paar laag. Het is niet helemaal 
duidelijk hoe dit lage broedsucces tot stand kwam, maar de meest aannemelijke verklaring is het optreden van een serie hoge vloeden in de kuikenperiode (en daardoor opgetreden sterfte onder kuikens).

Buiten de bovengenoemde gebieden werd in zes binnendijks gelegen locaties op Texel het broedsucces vastgelegd. Op een totaal van 127 paren (waarvan 82 paar in Dijkmanshuizen) werden 0,20 jong/paar genoteerd. Er waren geen specifieke mislukkingsoorzaken aan te wijzen.

Samenvattend kan worden gesteld dat in 2018 in geen van de onderzochte gebieden het broedsucces voldoende was om de populatie op peil te houden (0,5 - 1 jong per paar noodzakelijk). Dit past bij de in 2005-2017 verzamelde gegevens (Koffijberg et al. 2017).

\subsection{Kokmeeuw Chroicocephalus ridibundus - Black- headed Gull}

De Kokmeeuw is één van de talrijkste broedvogels in de Waddenzee, met in 201829.610 broedparen. Daarvan zaten er 16.917 op Griend (57\%). De populatie heeft sinds 1990 een flinke veer moeten laten, met over de hele Waddenzee gerekend een afname van gemiddeld $3 \%$ per jaar (sinds 2007 $4 \%$ per jaar) (Figuur 3.5). Op de vastelandskwelders zijn vrijwel alle kolonies verdwenen en lijkt er in de loop van een broedseizoen een groot verloop in locaties waar Kokmeeuwen zich vestigen. Kolonies van meer dan honderd paar (drie aan de Groninger kust, en één op Balgzand) zijn er zonder uitzondering goed beschermd tegen predatie: elektrische rasters bij Oterdum/Delfzijl en Punt van Reide en 'natuurlijke' barrières "broedrots Balgzand" en Ruidhorn aan de Groninger kust). Op Griend is het huidige aantal de helft van het aantal in het piekjaar 2008 (Lutterop \& Kasemier 2018).

In twee kolonies in het havengebied van Delfzijl werd een steekproef van nesten gevolgd om het nestsucces te bepalen. Deze hadden een nestsucces van 0,9\% (Schermdijk) en 64,0\% (Oterdum) (Mayfield, Tabel 3.3). De laatstgenoemde kolonie ligt op een locatie die zowel met water als een elektrisch raster tegen predatie is beschermd, de eerste kolonie is geheel onbeschermd (in ieder geval tegen landpredatoren). In beide kolonies was predatie de hoofdoorzaak van mislukken (waarschijnlijk voornamelijk predatie door grote meeuwen). Op de Schermdijk speelde door de geëxponeerde ligging ook hoog water een rol.

Tabel 3.3. Nestsucces van Kokmeeuw in het havengebied van Delfzijl in 2018 , bepaald door middel van de Mayfield methode. Weergegeven is de steekproef van gevolgde nesten, de dagelijke overlevingskans $(p)$ met standaarddeviatie ( $S d)$ en het uiteindelijke nestsucces met spreiding. Nest record data and nest succes according to Mayfield method in Black-headed Gull.

\begin{tabular}{|c|c|c|c|c|c|}
\hline Plaats & $\begin{array}{l}\text { Aantal } \\
\text { nesten }\end{array}$ & $\mathbf{p}$ & Sd & $\begin{array}{l}\text { Nestsucces } \\
(\%)\end{array}$ & $\begin{array}{l}\text { Spreiding Min- } \\
\operatorname{Max}(\%)\end{array}$ \\
\hline $\begin{array}{l}\text { Schermdijk haven Delfzijl } \\
\text { (onbeschermd) }\end{array}$ & 32 & 0,833 & 0,027 & 0,8 & $0,2-4,3$ \\
\hline Oterdum (met elektrisch raster) & 23 & 0,983 & 0,069 & 64,0 & $44,5-91,2$ \\
\hline
\end{tabular}

Van de negen kolonies waar het broedsucces werd vastgesteld waren er drie waar nul jongen werden grootgebracht (Schermdijk Delfzijl, Kwelder Hollum Ameland, Zandkes Texel). In de overige kolonies varieerde het aantal jongen per paar tussen 0,11 en 0,82. Twee kolonies op Texel (Dijkmanshuizen, Ottersaat) deden het verhoudingsgewijs goed (0,60-0,82 jong/paar), net als de door een raster beschermde kolonie bij Oterdum ( 0,63 jong/paar). Een andere afgerasterde kolonie op de Punt van Reide was minder succesvol ( $0,23 \mathrm{jong} / \mathrm{paar})$. De grote kolonie op Griend produceerde eveneens weinig jongen (naar schatting $0,28 \mathrm{jong} /$ paar). Het ongewogen gemiddelde van alle kolonies komt op $0,30 \mathrm{jong} /$ paar, wat ruim onder het niveau (ongeveer 1 jong/paar) ligt om op z'n minst een stabiele populatie te handhaven. Sinds de start van het meetnet in 2005 nam het broedsucces van Kokmeeuwen significant af (Figuur 4.10 in Koffijberg et al. 2017). De broedresultaten in 2018 lagen grofweg in dezelfde ordegrootte als die in de afgelopen jaren en zijn te laag voor instandhouding van de broedpopulatie als geheel. 


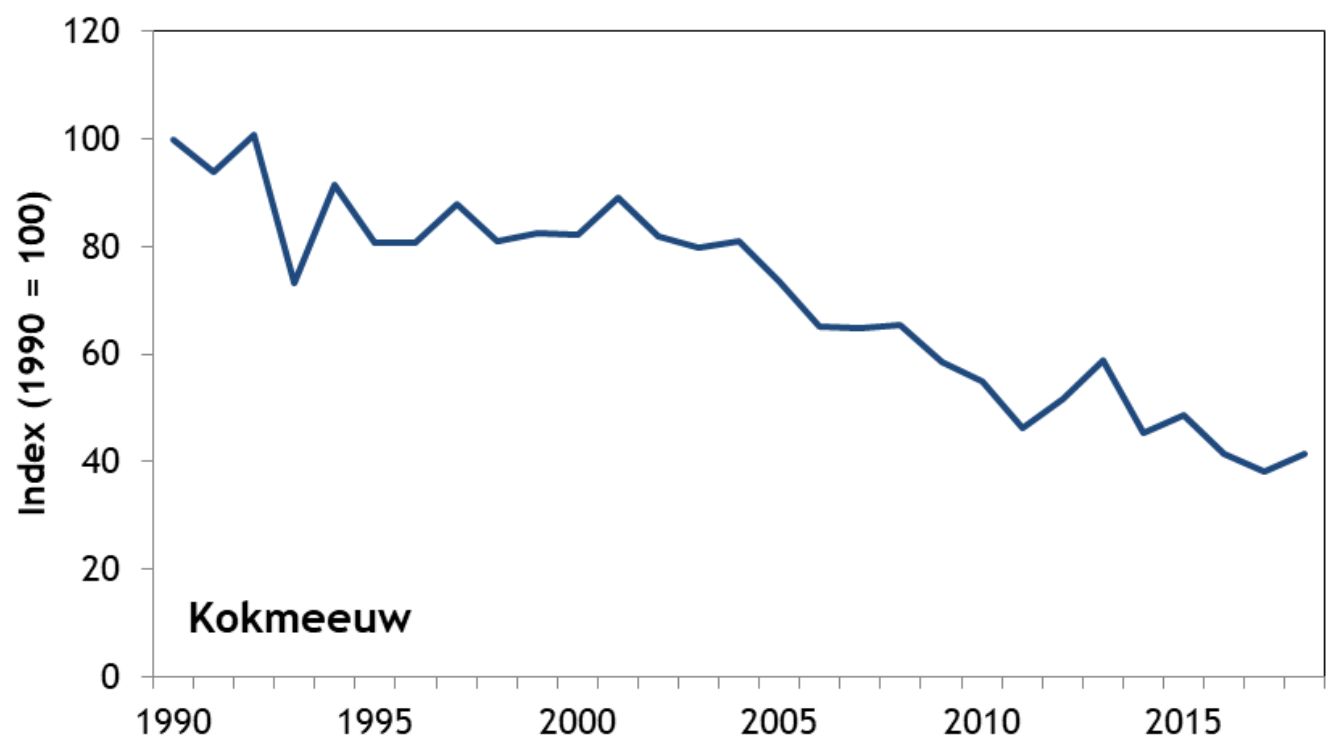

Figuur 3.5. Trend van Kokmeeuw als broedvogel in de Waddenzee (als index weergegeven met basisjaar 1990). Gegevens broedvogelmeetnet Sovon/CBS. Trends in breeding Black-headed Gull in the Dutch Wadden Sea (expressed as indices).

\subsection{Kleine Mantelmeeuw Larus fuscus - Lesser Black- backed Gull}

De verspreiding van Kleine Mantelmeeuwen kent een zwaartepunt in de duinen en op de strandvlaktes op de Waddeneilanden. Alle kolonies samen telden in 2018 bijna 32.000 paar. Na een langjarige toename zette de afgelopen jaren een negatief aantalsverloop in. Over de laatste 12 jaar (sinds 2007) gaat het om een afname van gemiddeld 3\% per jaar (Figuur 3.6). Het aantal binnen de begrenzing van het Natura 2000-gebied Waddenzee (17.207 paar) ligt nipt onder de geformuleerde instandhoudingsdoelstelling in het Natura 2000-beheerplan Waddenzee (19.000 paar). Ook op Texel ligt het huidige aantal onder de instandhoudingsdoelstelling, alleen op Vlieland erboven.

In 2018 werd zowel op Vlieland als Schiermonnikoog intensief onderzoek aan Kleine Mantelmeeuwen verricht. Op Schiermonnikoog kwam 89\% van de nesten uit (klassiek uitkomstpercentage, 84 nesten gevolgd), op Vlieland 17\% (klassiek percentage, 23 nesten gevolgd). Het nestsucces op Vlieland was laag in vergelijking met de tot nu toe verzamelde gegevens, maar specifieke oorzaken waren niet aan te wijzen ( $58 \%$ van de nesten was leeg zonder dat duidelijk werd wat de oorzaak was).

Het uiteindelijke broedsucces was voor beide kolonies vergelijkbaar, resp. 0,16 en 0,19 jong/paar. Op Vlieland lag dit in dezelfde ordegrootte als in 2017 (0,20 jong/paar), maar op Schiermonnikoog duidelijk lager (2017: 0,30 jong/paar). In de onderzoekskolonie van het NIOZ op Texel was het broedsucces eveneens laag (Kees Camphuysen, pers. med.). Er zijn aanwijzingen dat vooral de slechte voedselsituatie in de kuikenfase de meeuwen parten speelde (Kees Camphuysen, pers. med.).

De broedresultaten in 2018 steken negatief af bij de gemiddelde resultaten in de afgelopen jaren en behoren zelfs tot de laagste in de reeks vanaf 2005 (Figuur 4.12 in Koffijberg et al. 2017). Over die reeks bezien, is het aantal jongen dat Kleine Mantelmeeuwen produceren al geruime tijd onder het niveau dat nodig is om de populatie in stand te houden (ongeveer 0,6 - $1 \mathrm{jong} / \mathrm{paar}$ ). Het is aannemelijk dat de slechte broedresultaten ook een belangrijke drijfveer zijn voor de recent opgetreden afname. 


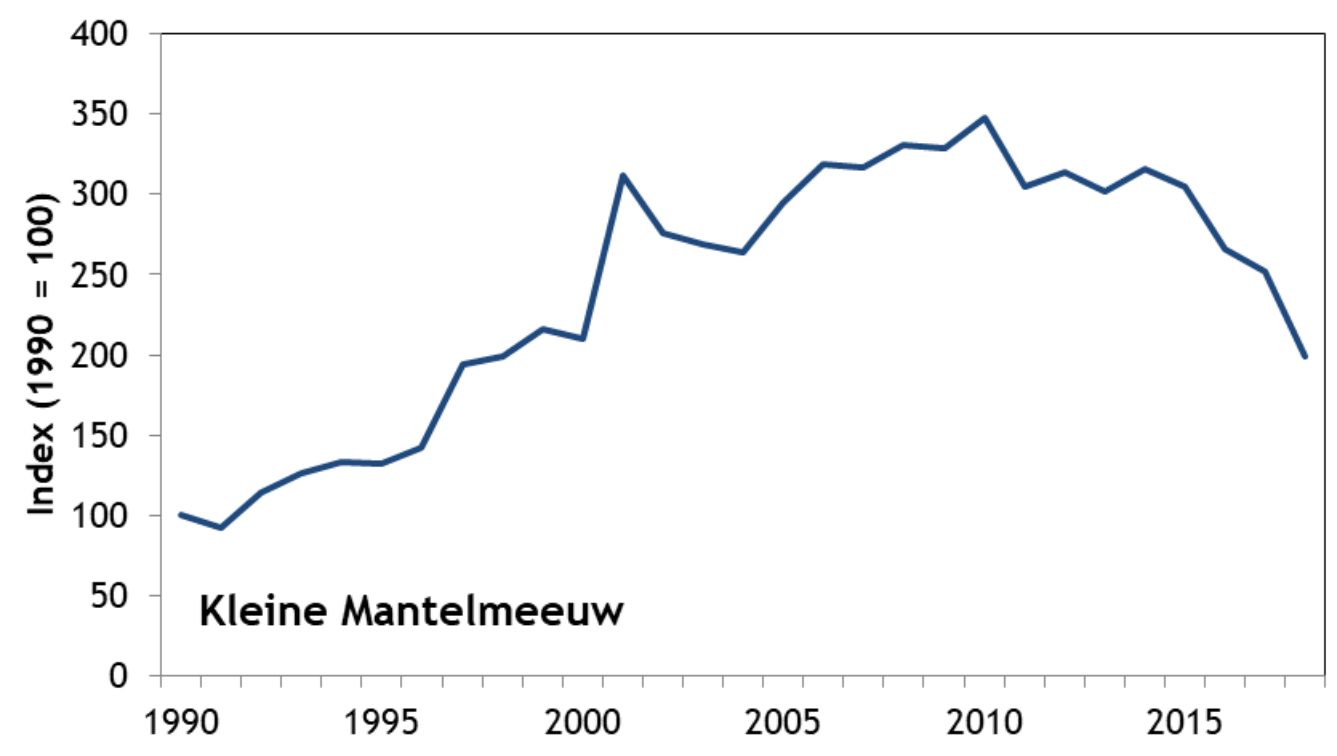

Figuur 3.6. Trend van Kleine Mantelmeeuw als broedvogel in de Waddenzee (aantal broedparen op grond van integrale tellingen, als index weergegeven met basisjaar 1990). Gegevens broedvogelmeetnet Sovon/CBS. Trends in breeding Lesser Black-backed Gull in the Dutch Wadden Sea (expressed as indices).

\subsection{Zilvermeeuw Larus argentatus - Herring Gull}

In 2018 broedden 16.745 Zilvermeeuwen in de Waddenzee, fors minder dan bij de laatste integrale telling in 2012. Zowel de lange termijn als korte termijn trend (sinds 2007) zijn negatief, met over de laatste 12 jaar een afname met gemiddeld 4\% per jaar (lange termijn -3\% per jaar) (Figuur 3.7).

Onderzoek aan broedsucces vond in dezelfde gebieden plaats als bij Kleine Mantelmeeuw (beide soorten broeden ook gemengd). Het nestsucces (klassiek) op Schiermonnikoog bedroeg $90 \%$ (32 nesten gevolgd), op Vlieland duidelijk lager, 38\% (24 nesten gevolgd). Het nestsucces op Vlieland behoorde tot de laagste in de reeks sinds 2005. Meer dan de helft van de nesten op Vlieland (53\%) in 2018 viel ten prooi aan predatie.

Het uiteindelijke broedsucces was hoger dan bij Kleine Mantelmeeuw en liep uiteen van 0,50 (Vlieland) tot 0,75 (Schiermonnikoog) jong/paar. Het broedsucces op Texel lag in dezelfde orde van grootte als op Vlieland (Kees Camphuysen, pers. med.). Net als 2017 deden Zilvermeeuwen het dus opnieuw beter dan de Kleine Mantelmeeuwen. Zilvermeeuwen in de oostelijke Waddenzee lijken bovendien beter af dan in de westelijke Waddenzee, maar de steekproef is met twee kolonies beperkt. De in 2018 verzamelde gegevens pasten goed in het beeld van de voorgaande jaren (zie Figuur 4.14 in Koffijberg et al. 2017). Het broedsucces is te laag om de populatie Zilvermeeuwen op peil te houden, uitgaande van de dan benodigde 0,6 - 1 jong per paar. 


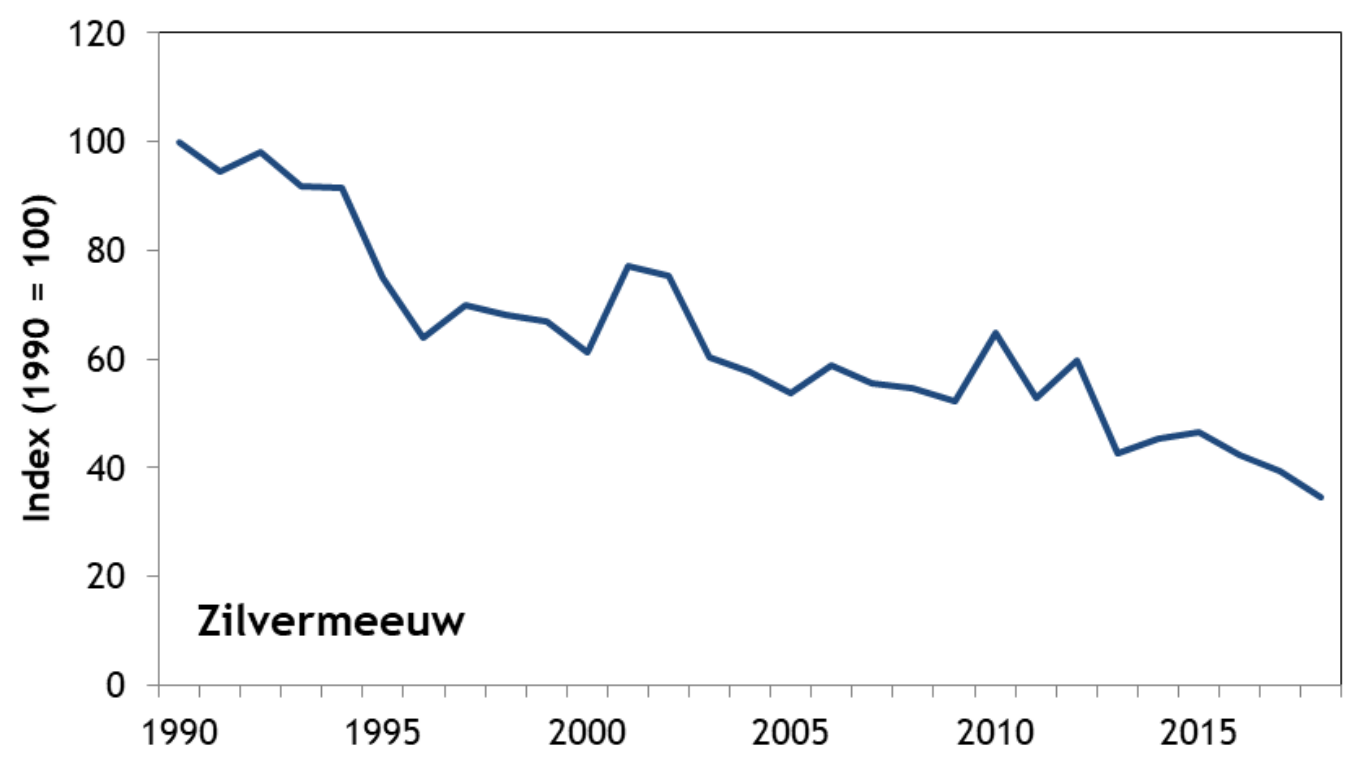

Figuur 3.7. Trend van Zilvermeeuw als broedvogel in de Waddenzee (aantal broedparen op grond van integrale tellingen, als index weergegeven met basisjaar 1990). Gegevens broedvogelmeetnet Sovon/CBS. Trends in breeding Herring Gull in the Dutch Wadden Sea (expressed as indices).

\subsection{Grote Stern Sterna sandvicensis - Sandwich Tern}

Het aantal broedende Grote Sterns in de Waddenzee was de afgelopen jaren aan enige fluctuatie onderhevig en was in 2018 met 8204 paar aan de lage kant. Bovendien waren al deze vogels gevestigd in slechts drie kolonies: Griend en twee binnendijkse broedplaatsen op Texel (Utopia en Wagejot). De voorheen belangrijke kolonie op de kwelder van Hollum op Ameland was in 2018 onbezet. Buiten de Waddenzee is een nieuwe binnendijkse kolonie in De Putten bij Camperduin de afgelopen jaren sterk in opkomst (1700 paar in 2018). Op langere termijn (sinds 1990) wordt de stand in de Waddenzee nog als stabiel geclassificeerd, maar sinds 2007 domineren fluctuaties (Figuur 3.8). Hoewel niet alle Grote Sterns momenteel binnen de begrenzing van het Natura 2000-gebied Waddenzee broeden, is wel duidelijk dat de huidige aantallen ver beneden de instandhoudingsdoelstelling in het Natura 2000-beheerplan (16.000 paar) liggen.

Het broedsucces in de kolonie op Griend bedroeg naar schatting 0,50 jong/paar. In Utopia en Wagejot op Texel ging het om resp. 0,67 en 0,70 jong/paar. Dit komt goed overeen met de situatie in 2017, zij het dat op Griend nu duidelijk minder jongen werden grootgebracht. De broedresultaten op Griend waren zowel in 2017 als 2018 beter dan in 2011-2016 (Lutterop \& Kasemir 2018), en dat geldt ook voor de Waddenzee als geheel (zie Figuur 4.16 in Koffijberg et al. 2017). 


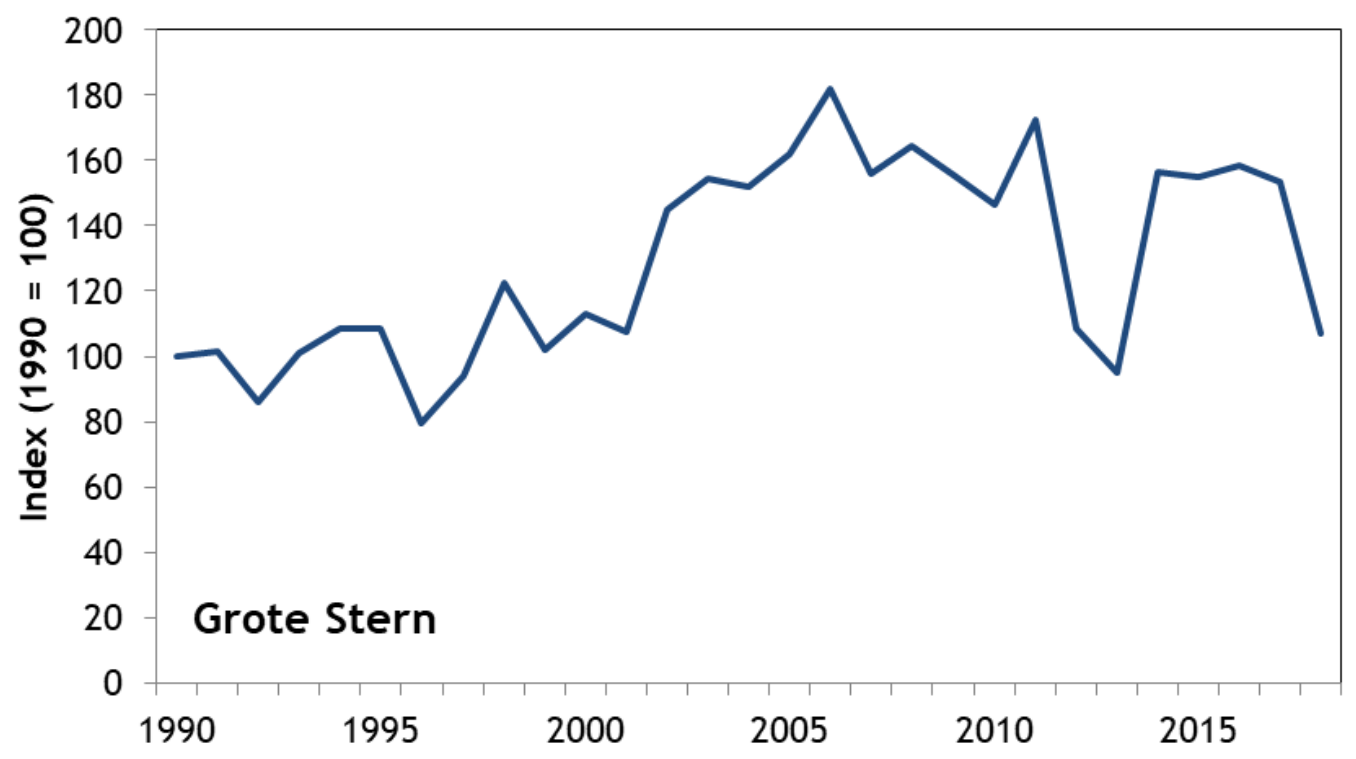

Figuur 3.8. Trend van Grote Stern als broedvogel in de Waddenzee (aantal broedparen op grond van integrale tellingen, als index weergegeven met basisjaar 1990). Gegevens broedvogelmeetnet Sovon/CBS. Trends in breeding Sandwich Tern in the Dutch Wadden Sea (expressed as indices).

\subsection{Visdief Sterna hirundo - Common Tern}

De broedpopulatie in de Waddenzee in 2018 telde 2810 paar. Sinds de start van de tellingen in 1990 is er sprake van een significante afname met gemiddeld 4\% per jaar (Figuur 3.9). Over de laatste 12 jaar (sinds 2007) is de populatie op een lager niveau gestabiliseerd. De westelijke en oostelijke Waddenzee volgen grotendeels dit patroon, maar in de Eems-Dollard namen de aantallen op lange termijn significant toe (laatste 12 jaar onzeker). Deze verschillen zijn vooral uiting van een dynamisch vestigingspatroon, waarbij in de Eems-Dollardregio in de loop der jaren diverse nieuwe broedmogelijkheden ontstonden in het havengebied van Eemshaven en Delfzijl (en recent via een nieuw aangelegd broedeiland "Stern", De Boer \& Koffijberg 2019). Dit heeft niet geleid tot een algeheel herstel van de populatie in de Waddenzee, maar eerder tot een herverdeling van broedvogels. Het huidige aantal broedvogels in de Waddenzee ligt ver onder de instandhoudingsdoelstelling zoals die in het Natura 2000-beheerplan is geformuleerd (5.300 paar).

Informatie over het broedsucces was in 2018 beschikbaar van 13 locaties, met de nadruk op de kuikenfase. Nestsucces (Mayfield) werd bepaald in vier kolonies (Tabel 3.4) en was hoog in de kolonies bij Oterdum/Delfzijl (82,5\%), het nieuwe eiland "Stern" in de Eems $(79,2 \%)$ en op de Vliehors/Vlieland $(65,4 \%)$, maar laag op de Schermdijk in de haven van Delfzijl $(4,5 \%)$. Op de Schermdijk gingen nesten verloren door hoge vloed (7) en predatie (5), maar bleef de oorzaak bij veel andere nesten (13) onbekend. Op Rottumerplaat ging een kolonie van 86 nesten verloren door een hoge vloed op 22 juni (klassiek nestsucces $0 \%$ ). Het nestsucces in het havengebied van Delfzijl was vergelijkbaar met 2017: hoog bij Oterdum, waar de kolonie door een elektrisch raster (en een waterkering) tegen predatie door grondpredatoren wordt beschermd, laag op de Schermdijk. Op Vlieland waren de legsels succesvoller dan in 2017. 
Tabel 3.4. Nestsucces van Visdief in de Waddenzee in 2018, bepaald door middel van de Mayfield methode. Weergegeven is de steekproef van gevolgde nesten, de dagelijke overlevingskans $(p)$ met standaardeviatie (Sd) en het uiteindelijke nestsucces met spreiding. Nest record data and nest succes according to Mayfield method in Common Tern.

\begin{tabular}{lrrrrr} 
Plaats & Aantal & $p$ & Sd & $\begin{array}{c}\text { Nestsucces } \\
(\%)\end{array}$ & $\begin{array}{c}\text { Spreiding Min-Max } \\
(\%)\end{array}$ \\
Eesten & 76 & 0,980 & 0,003 & 79,2 & $67,3-93,0$ \\
\hline Eems, schermdijk Delfzijl & 26 & 0,879 & 0,023 & 4,5 & $1,3-14,7$ \\
\hline Eems, Oterdum & 40 & 0,992 & 0,004 & 82,5 & $69,7-97,6$ \\
\hline Vlieland, Vliehors & 23 & 0,982 & 0,008 & 65,4 & $44,9-94,6$ \\
\hline
\end{tabular}

Van de 13 gevolgde kolonies mislukten er 8 volledig (nul vliegvlugge jongen) of leverden amper jongen op (0,02-0,06 jong/paar). Tot die laatste categorie behoorde ook de grote kolonie op Griend, die in juli vrijwel volledig was verlaten en waar in de kuikenfase verliezen optraden door slecht weer en stuivend zand (Lutterop \& Kasemier 2018). Twee kolonies waren wel succesvol, maar leverden een laag aantal jongen op (Punt van Reide, 0,18 jong/paar, Vliehors/Vlieland 0,29 jong per paar), ondanks dat de eerste kolonie door een elektrisch raster tegen grondpredatoren is omgeven. Buitengewoon goed presteerde de kolonie bij Oterdum (1,01 jong/paar) en die op het nieuwe eiland "Stern" $(1,05$ jong/paar). Beide kennen een optimale bescherming tegen landpredatoren, maar waren kennelijk ook qua voedselbeschikbaarheid in staat veel jongen groot te brengen. Het ongewogen gemiddelde van alle kolonies samen komt op 0,24 jong/paar, wat aan de lage kant is. Maar er is enorme variatie tussen kolonies. De beide goed presterende kolonies in het Eems-Dollard gebied zijn daarbij wellicht eerder positieve uitzonderingen op de regel, gezien het grote aantal kolonies waar (bijna) geen jongen groot komen. Verliesoorzaken waren niet overal even duidelijk, maar in ieder geval op Rottumerplaat, de Schermdijk in Delfzijl en op de Vliehors speelden hoge vloeden in de nestfase een rol.

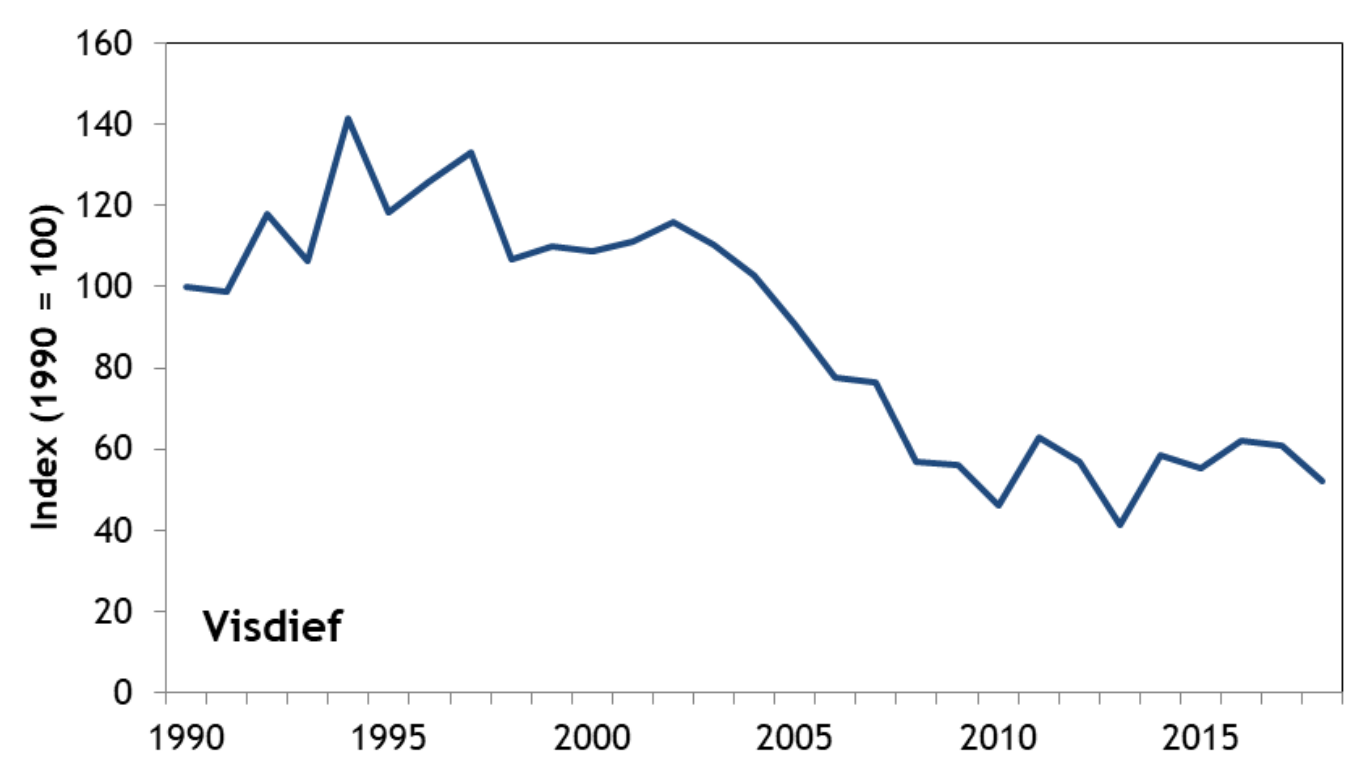

Figuur 3.9. Trend van Visdief als broedvogel in de Waddenzee (aantal broedparen op grond van integrale tellingen, als index weergegeven met basisjaar 1990). Gegevens broedvogelmeetnet Sovon/CBS. Trends in breeding Common Tern in the Dutch Wadden Sea (expressed as indices).

\subsection{Noordse Stern Sterna paradisaea - Arctic Tern}

Bij de 870 paar Noordse Sterns die in 2018 verdeeld over 19 kolonies in de Waddenzee broedden gaat het om het grootste deel van de Nederlandse broedpopulatie. De soort komt bovendien sterk geconcentreerd in enkele kolonies voor: 59\% van het aantal broedde in slechts drie kolonies, op de kwelder van Hollum, Griend en de Punt van Reide aan de Dollard. Sinds 1990 nam het aantal met 
gemiddeld 3\% per jaar af, maar recent is de trend door sterke fluctuaties onzeker (Figuur 3.10). Net als bij Visdief zijn er verschillen binnen de Waddenzee: een lange termijn toename in het EemsDollard regio (vergelijkbaar proces als bij Visdief beschreven) en een blijvende afname in de westelijke Waddenzee in de laatste 12 jaar.

In drie kolonies werden nestgegevens verzameld. Op de Schermdijk in de haven van Delfzijl mislukten alle nesten door predatie door Bruine rat en een hoogtij. Op het nieuwe eiland "Stern" in de Eems en op de Vliehors op Vlieland was bijna driekwart van de nesten succesvol (Tabel 3.5). Het aantal uitgevlogen jongen was op de Vliehors evenwel laag $(0,19$ jong/paar, verliezen door hoge vloed rond 22 juni). De broedvogels op het nieuwe eiland "Stern" waren daarentegen succesvoller en brachten 0,87 jong per paar groot. De overige kolonies (Griend, Punt van Reide, Dijkmanshuizen/Texel) mislukten geheel of hadden amper succes (0,1 jong/paar op Griend). Op Griend kampten de vogels met slecht weer en stuivend zand (Lutterop \& Kasemier 2018). Het grote aantal mislukte kolonies is niet nieuw en werd ook in voorgaande jaren vastgesteld. Het voorbeeld van het nieuwe broedeiland in de Eems laat evenwel zien dat de soort wel succesvol kan zijn.

Tabel 3.5. Nestsucces van Noordse Stern in de Waddenzee in 2018, bepaald door middel van de Mayfield methode. Weergegeven is de steekproef van gevolgde nesten, de dagelijke overlevingskans (p) met standaardeviatie (Sd) en het uiteindelijke nestsucces met spreiding. Nest record data and nest succes according to Mayfield method in Arctic Tern.

\begin{tabular}{lrllll} 
Plaats & $\begin{array}{r}\text { Aantal } \\
\text { nesten }\end{array}$ & P & Sd & $\begin{array}{l}\text { Nestsucces } \\
(\%)\end{array}$ & $\begin{array}{l}\text { Spreiding Min- } \\
\text { Max (\%) }\end{array}$ \\
\hline Eems, broedeiland Stern & 23 & 0,986 & 0,008 & 73,2 & $51,3-100$ \\
\hline Vlieland, Vliehors & 14 & 0,985 & 0,008 & 71,2 & $48,4-100$ \\
\hline
\end{tabular}

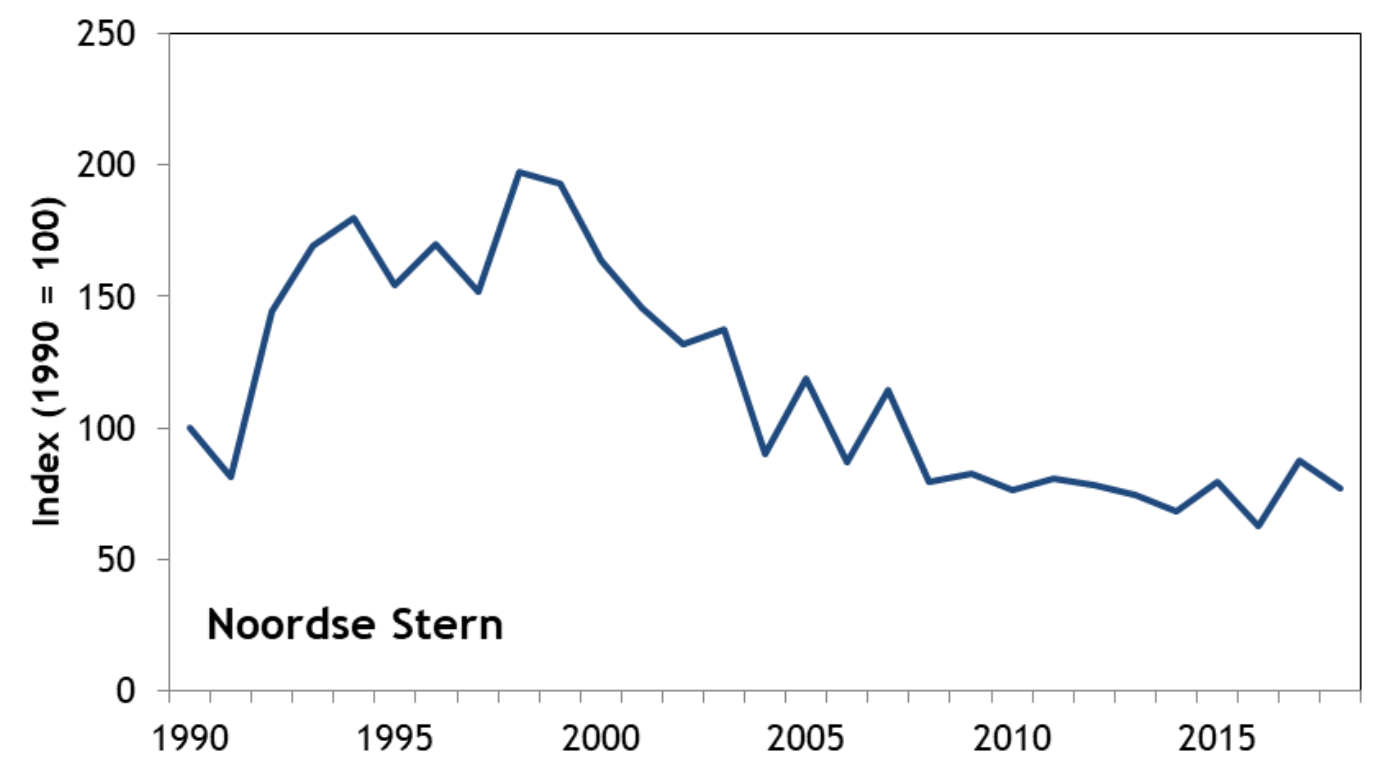

Figuur 3.10. Trend van Noordse Stern als broedvogel in de Waddenzee (als index weergegeven met basisjaar 1990). Gegevens broedvogelmeetnet Sovon/CBS. Trends in breeding Arctic Tern in the Dutch Wadden Sea (expressed as indices). 


\section{$4 \quad$ Conclusies en discussie}

In de Nederlandse Waddenzee worden sinds 2005 metingen aan het broedsucces van kustbroedvogels gedaan, tegenwoordig in het kader van het Meetnet Reproductie en als onderdeel van het Netwerk Ecologische Monitoring (NEM) en het trilaterale TMAP-programma. De gegevens die voor het Meetnet Reproductie in 2018 op ruim 70 locaties verspreid over de Waddenzee werden verzameld, laten zien dat voor zeven van de tien onderzochte soorten, namelijk Scholekster, Kluut, Kokmeeuw, Kleine Mantelmeeuw, Zilvermeeuw, Visdief en Noordse Stern, het broedsucces (aantal vliegvlugge jongen per paar), gemiddeld genomen over de hele Waddenzee, structureel aan de lage kant is om de broedpopulatie op termijn op peil te houden (uitzonderingen op specifieke locaties, zie verderop). Bij Kleine Mantelmeeuw behoorden de broedprestaties tot de slechtste in de reeks tot nu toe. De drie overige soorten hadden in 2018 wisselende broedresultaten: redelijk tot goed bij Lepelaar (zij het steekproef), beter dan in voorgaande jaren bij Eider (zowel in nestfase (Vlieland) als bij jongentelling, maar enkele belangrijke gebieden evenwel geen gegevens) en redelijk tot goed bij Grote Stern (grote variatie per locatie).

Predatierisico en wegspoelen door een hoogtij zijn belangrijke oorzaken van mislukken. Maar lang niet bij alle soorten en locaties beschikken we over goede gegevens om precies te kunnen kwantificeren in welke verhouding de verschillende verliesoorzaken tot elkaar staan, of is onbekend wie een rol speelt als predator. Bovenal ontbreekt het in de Nederlandse Waddenzee aan kennis hoe predatoren, speciaal landzoogdieren, in buitendijkse gebieden te werk gaan, en wat bepaalt of nesten en kolonies van kustbroedvogels worden gepredeerd (Leyrer et al. 2019). Zo waren in 2019 meer broedvogels succesvol, omdat landpredatoren waarschijnlijk overschakelden op de in overvloed beschikbare veldmuizen. Bij Kleine Mantelmeeuw hing het slechte broedseizoen waarschijnlijk samen met ongunstige voedselomstandigheden (Kees Camphuijsen/NIOZ, pers. med). Het is minder duidelijk of dit ook bij andere soorten speelt. Het is in eerdere jaarrapportages gesuggereerd voor Eider, Scholekster, Noordse Stern en Visdief. Bij de laatste twee soorten laten de voorbeelden in de EemsDollardregio echter zien dat in ieder geval in 2018 dit aspect in die regio geen zichtbare rol speelde. Vooral in de context van aanleg van broedgebieden in de toekomst is het echter wenselijk inzicht te krijgen in de voedselbeschikbaarheid en variatie daarin binnen de Waddenzee voor visetende soorten, opdat nieuwe broedgebieden niet als ecologische val gaan fungeren omdat ze worden aangelegd op een locatie die te ver van geschikt foerageergebied ligt.

De in 2018 verzamelde gegevens bevestigen grotendeels de resultaten van voorgaande jaren. Eerdere analyses toonden ook aan dat het uitblijven van goede broedresultaten bij een hele serie soorten een sturende factor is bij de krimpende populaties kustbroedvogels in de Waddenzee (Van der Jeugd et al. 2014). En dat gaat dan waarschijnlijk niet alleen op voor de Nederlandse Waddenzee, maar ook voor de Duitse en Deense Waddenzee, waar grotendeels dezelfde soorten met een laag broedsucces worden geconfronteerd en veel soorten eveneens afnemen (Thorup \& Koffijberg 2015). Of dit ook in recente jaren nog het geval was, zal een voor komend jaar geplande trilaterale analyse van broedsucces-gegevens moeten uitwijzen.

Bij vrijwel alle soorten zien we ook (positieve) uitzonderingen op de regel. Zo lijken legsels van Scholeksters in de polders op de Waddeneilanden succesvoller uitgebroed te worden (Ameland) of brengen ze juist wel voldoende jongen groot (Banckspolder op Schiermonnikoog), al zou het wenselijk zijn meer locaties in de polders op de eilanden te onderzoeken om te kijken of dit representatief is voor het binnendijkse (landbouw)gebied op de eilanden (dat in 2018 goed was voor maar liefst $79 \%$ van alle broedende Scholeksters in de Waddenzee, Boele et al. 2020). Bij Kluut maakte een inrichtingsmaatregel op de Dollardkwelder een belangrijk verschil. Op een nieuw ingericht eiland in een kleiput, omgeven door water en een hekwerk, was $91 \%$ van de legsels succesvol (Mayfield), terwijl onbeschermde nesten op twee locaties in de nabije omgeving vanwege hoog predatierisico hooguit 5\% nestsucces hadden (zie ook Bos et al. 2018b), vergelijkbaar met de meeste eerdere jaren op de Dollardkwelder, voor aanleg van het broedeiland. Waarschijnlijk door hoge tijen in de 
kuikenperiode, was het uiteindelijke broedsucces in de Dollard toch laag (in 2019 kwamen beduidend meer jongen groot). Bescherming van nesten is dus niet een garantie dat het hele broedseizoen succesvol verloopt, omdat het in de kuikenfase alsnog mis kan gaan.

Een ander special geval zijn broedende Kokmeeuwen, Visdieven en Noordse Sterns in de EemsDollardregio. Ook hier zijn er wisselende resultaten met toepassing van elektrische rasters om predatie tegen te gaan (succesvol bij Oterdum in de haven van Delfzijl, minder succesvol op de Punt van Reide aan de Dollard, zowel bij Kokmeeuw als Visdief). Een in 2018 aangelegd broedeiland ("Stern") dat speciaal voor Visdief en Noordse Stern in de Eems ten zuiden van de Eemshaven werd ingericht kende direct in het eerste jaar succesvolle vestigingen van beide soorten (De Boer \& Koffijberg 2019). Niet alleen waren legsels succesvol, ook het aantal uitgevlogen jongen was met 0,87 jong/paar (Noordse Stern) en 1,05 jong/paar (Visdief) beduidend groter dan elders, en zou bovendien (ruim) voldoende zijn om de populatie op peil te houden. Dit laat zien dat indien een aantal randvoorwaarden bij elkaar komen (veilige broedplaats, waarschijnlijk gunstige voedselsituatie) deze soorten succesvol kunnen zijn.

De slechte broedresultaten zullen ook gevolgen hebben voor het aantal broedparen dat zich in de Waddenzee vestigt, zoals de eerdere analyse van Van der Jeugd et al. (2014) liet zien. Resultaten van de aantalsmonitoring die in het kader van het Netwerk Ecologische Monitoring worden verzameld, laten zien dat de meeste soorten die in het Meetnet Reproductie worden gevolgd, in de periode 19902018 significant in aantal afnamen, doorgaans met gemiddeld 3-4\% per jaar (Eider, Scholekster, Kokmeeuw, Kleine Mantelmeeuw, Zilvermeeuw, Visdief en Noordse Stern), maar in geval van Kluut met 6\% per jaar (Boele et al. 2020). Binnen de Waddenzee is er soms variatie in de mate waarin deze ontwikkelingen plaatsvinden. Lepelaar (toename) en Grote Stern (stabiel) zijn de enige soorten die niet in de achteruitgang delen, al is het aantal Grote Sterns recent wel minder groot dan een aantal jaren geleden (trend momenteel fluctuerend). De eerdere groei van de Lepelaar is recent afgezwakt, omdat dichtheidsafhankelijke factoren een rem zetten op een verdere uitbreiding (Lok et al. 2009, 2013; Oudman et al. 2017). De in 2018 in de Waddenzee broedende aantallen liggen voor Eider, Kluut, Grote Stern, Visdief en Noordse Stern duidelijk onder de geformuleerde instandhoudingsdoelstellingen die in het beheerplan Waddenzee worden genoemd. Bij Kleine Mantelmeeuw is de discrepantie tussen huidige aantallen en instandhoudingsdoelstellingen minder groot, maar als de huidige negatieve trend doorzet zullen de aantallen onder de instandhoudingsdoelstellingen duiken. 


\section{Literatuur}

Beintema A.J. (1992). Mayfield moet: oefeningen in het berekenen van uitkomstsucces. Limosa 65: 155-162.

Boele A., van Bruggen J., Hustings F., van Kleunen A., Koffijberg K., Vergeer J.W. \& van der Meij T. (2020). Broedvogels in Nederland in 2018. Sovon-rapport 2020/07. Sovon Vogelonderzoek Nederland, Nijmegen.

De Boer P. (2019). Broedvogels van de Klutenplas in 2018: aantallen en broedsucces. Sovon-rapport 2019/07. Sovon Vogelonderzoek Nederland, Nijmegen.

De Boer P. \& Koffijberg K. (2019). Broedvogels en broedsucces van Visdief en Noordse Stern op het broedeiland 'Stern' in de Eems in 2018. Sovon-rapport 2019/06. Sovon Vogelonderzoek Nederland, Nijmegen.

De Boer P., Oosterbeek K., Koffijberg K., Ens B., Smit C. \& de Jong M. (2007). Broedsucces van kustbroedvogels in de Waddenzee in 2006. SOVON-monitoringrapport 2007/03, IMARES-rapport C036/08. SOVON Vogelonderzoek Nederland/IMARES, Beek-Ubbergen/Den Burg.

Bos D., Kleefstra R., Hoekema F. \& Koffijberg K. (2018a). Broedvogel- en ganzenmonitoring op de Dollard in 2017. Nul-monitoring in 2017 i.r.t. de Brede Groene Dijk. A\&W-rapport 2415, Veenwouden.

Bos D., L. Bruinzeel L., Kleefstra R, \& Koffijberg K. (2018b). Broedvogel- en ganzenmonitoring op de Dollard in 2018. Eerste jaar met Kleirijperij en broedeiland. A\&W-rapport 2506, Altenburg \& Wymenga Ecologisch Onderzoek, Feanwâlden.

Camphuysen C.J., Berrevoets C.M., Cremers H.J.W.M., Dekinga A., Dekker R., Ens B.J., van der Have T.M., Kats R.K.H., Kuiken T., Leopold M.F., van der Meer J. \& Piersma T. (2002). Mass mortality of common eiders (Somateria mollissima) in the Dutch Wadden Sea, winter 1999/2000: starvation in a commercially exploited wetland of international importance. Biological Conservation 106: 303317.

Camphuysen C.J. (2013). A historical ecology of two closely related gull species (Laridae): multiple adaptations to a man-made environment. PhD Thesis, Univ. of Groningen, Groningen.

CBS (2013). Kwaliteitsrapportage Netwerk Ecologische Monitoring. CBS, Den Haag.

Duriez O., Ens B.J., Choquet R., Pradel R. \& Klaassen M. (2012). Comparing the seasonal survival of resident and migratory oystercatchers: carry-over effects of habitat quality and weather conditions. Oikos 121: 862-873.

Van der Jeugd H.P, Ens B.J., Versluijs M. \& Schekkerman H. (2014). Geïntegreerde monitoring van vogels van de Nederlandse Waddenzee. Vogeltrekstation rapport 2014-01. Vogeltrekstation, Wageningen; CAPS-rapport 2014-01; Sovon-rapport 2014/18, Sovon Vogelonderzoek Nederland, Nijmegen.

Kats R.K.H. (2007). Common Eiders Somateria mollissima in the Netherlands: The rise and fall of breeding and wintering populations in relation to the stocks of shellfish. PhD-thesis, Universiteit of Groningen.

Van Kleunen A., Koffijberg K., de Boer P., Nienhuis J., Camphuysen C.J., Schekkerman H., Oosterbeek K., de Jong M., Ens B. \& Smit C. (2010). Broedsucces van kustbroedvogels in de Waddenzee in 2007 en 2008. Sovon-monitoringrapport 2010/04, IMARES-rapport C169/10. Sovon Vogelonderzoek Nederland, Nijmegen, IMARES, Texel \& WOT/Alterra, Wageningen.

Van Kleunen A., de Boer P., Koffijberg K., Oosterbeek K. Nienhuis J., de Jong M.L., Smit C.J. \& van Roomen M. (2012). Broedsucces van kustbroedvogels in de Waddenzee in 2009 en 2010. WOtwerkdocument 346. Wettelijke Onderzoekstaken Natuur \& Milieu, Wageningen.

Koffijberg K. \& Smit C. (2013). Broedsucces van kenmerkende kustbroedvogels in de Waddenzee in mineur. WOt paper 25. Wettelijke Onderzoekstaken Natuur \& Milieu, Wageningen.

Koffijberg K., Schrader S. \& Hennig, V. (2011). TMAP Manual breeding success, $2^{\text {nd }}$ version 2011. Common Wadden Sea Secretariat, Wilhelmshaven.

Koffijberg K., Laursen K., Hälterlein B., Reichert G., Frikke J. \& Soldaat L. (2015a). Progres report trends of breeding birds in the Wadden Sea 1991-2013. Wadden Sea Ecosystem 35. Common 
Wadden Sea Secretariat, Trilateral Monitoring and Assessment Group, Joint Monitoring Group of Breeding Birds in the Wadden Sea, Wilhelmshaven.

Koffijberg K., de Boer P., Hustings F., van Kleunen A., Oosterbeek K. \& Cremer J. (2015b).

Broedsucces van kustbroedvogels in de Waddenzee in 2011-2013. Sovon-rapport 2015/61,IMARES-rapport C153/15. Sovon Vogelonderzoek Nederland, Nijmegen, IMARES, Den Helder \&WOT/Alterra, Wageningen.

Koffijberg K., Frikke J., Hälterlein B., Reichert G. \& Andretzke H. (2016a). Breeding birds in trouble: a framework for an action plan in the Wadden Sea. CWSS, Wilhelmshaven.

Koffijberg K., Cremer J, de Boer, P., Postma J. \& Oosterbeek K. (2016b). Broedsucces van kustbroedvogels in de Waddenzee in 2014. WOt-technical report 78 / Sovon-rapport 2016/11 / Wageningen Marine Research-rapport C112/16. WOT Natuur \& Milieu - WUR, Wageningen /Sovon Vogelonderzoek Nederland, Nijmegen / Wageningen Marine Research, Den Helder.

Koffijberg K., Cremer J., de Boer P., Nienhuis J., Schekkerman H.; Oosterbeek K. \& Postma J. (2017). Broedsucces van kustbroedvogels in de Waddenzee in 2015-2016 en trends in broedsucces in 2005-2016. Sovon-rapport 2017/66, Wageningen Marine Research-rapport C100/17. Sovon Vogelonderzoek Nederland, Nijmegen, Wageningen Marine Research, Den Helder \& WOT/Alterra, Wageningen.

Koffijberg K., Cremer J., de Boer P., Nienhuis J., Oosterbeek K. \& Postma J. (2018). Broedsucces van kustbroedvogels in de Waddenzee in 2017. Sovon-rapport 2018/72, Wageningen Marine Researchrapport C089/18. Sovon Vogelonderzoek Nederland, Nijmegen, Wageningen Marine Research, Den Helder \& WOT/Alterra, Wageningen.

Leyrer J., Frikke J., Hälterlein B., Koffijberg K., Körber P., Reichert G., (2019). Managing predation risk for breeding birds in the Wadden Sea. Results from a workshop in Tönning, Schleswig-Holstein, 78 March 2017. Wadden Sea Ecosystem No. 38. Common Wadden Sea Secretariat, Joint Monitoring Breeding Bird Group (JMBB) in the Wadden Sea, Wilhelmshaven, Germany

Lilipaly S.J., Wolf P.A., Sluijter M., Arts F.A., Hoekstein M.S.J. \& van Straalen K.D. 2019. Broedsucces van kustbroedvogels in het Deltagebied in 2018. Delta ProjectManagement Rapportnr. 2018-09. DPM, Vlissingen.

Lok T., Overdijk O., Horn H. \& Piersma T. (2009). De lepelaarpopulatie van de Wadden. Komt het einde van de groei in zicht? Limosa 82: 149-157.

Lok T., Overdijk O., Tinbergen J.M. \& Piersma T. (2013). Seasonal variation in density dependence in age-specific survival of a long-distance migrant. Ecology 94: 2358-2369.

Lutterop D. \& Kasemir G. (2018). Griend Broedvogels en Bewaking 2018. Rapport Vereniging Natuurmonumenten, 's-Graveland.

Mayfield H. (1961). Nesting Success Calculated from Exposure. The Wilson Bulletin 73 (3): 255-261. Mayfield H.F. (1975). Suggestions for Calculating Nest Success. The Wilson Bulletin 87(4): 456-466.

Oosterhuis R., Dijksen L.J., Ens B.J., Foppen R., de Jong M., Kats, R.K.H., Koks B.J., van Turnhout C. \& Willems F. (2004). Naar een reproductiemeetnet voor broedvogels in de Waddenzee. Alterrarapport 944 / SOVON-onderzoeksrapport 2004/03. Alterra/SOVON Vogelonderzoek Nederland, Wageningen/Beek-Ubbergen.

Oudman T., de Goeij P., Piersma T. \& Lok T. (2017). Colony-breeding Eurasian Spoonbills in The Netherlands: local limits to population growth with expansion into new areas. Ardea 105, doi: 10.5253/arde.v105i2.a2.

PRW (2018). Actieplan broedvogels Waddenzee. Programma naar een Rijke Waddenzee, Leeuwarden.

Reneerkens J., Piersma T., Spaans B. (2005). De Waddenzee als kruispunt van vogeltrekwegen. Literatuurstudie naar de kansen en bedreigingen van wadvogels in internationaal perspectief. NIOZ-report 2005-4, Texel.

Schekkerman H., Arts F.A., van der Jeugd H., Stienen E.W.M. \& van Roomen M. (2017). Naar een demografische analyse van populaties van karakteristieke vogels in het Deltagebied. Sovonrapport 2017/58, CAPS-rapport 2017/01. Sovon Vogelonderzoek Nederland/Vogeltrekstation/Delta Project Management/Instituut voor Natuur en Bosonderzoek, Nijmegen.

Spaans B., Leopold M. \& Plomp M. (2018). Bepaling van het aantal nesten en het uitvliegsucces van Grote Sterns op Texel met behulp van een drone. Limosa 91: 30-37.

Thorup O. \& Koffijberg K. (2015). Breeding success in the Wadden Sea in 2009-2012: a review. Wadden Sea Ecosystem 36. Common Wadden Sea Secretariat, Wilhelmshaven.

Van Turnhout C. (2008). Nestkaartenproject gaat 14e jaar in. SOVON-Nieuws 21 (1) 11-12. 
Willems F., Oosterhuis R., Dijksen L., Kats R. \& Ens B. (2005). Broedsucces van kustbroedvogels in de Waddenzee 2005. SOVON-onderzoeksrapport 2005/07 / Alterra-rapport 1265. SOVON Vogelonderzoek Nederland, Beek-Ubbergen / Alterra, Texel. 



\section{Verantwoording en dankwoord}

WOt-technical report: 183

Projectnummer: WOT-04-009-035.04

Wettelijke Onderzoekstaken Natuur \& Milieu (WOT N\&M) hecht grote waarde aan de kwaliteit van onze eindproducten. Een review van de rapporten op wetenschappelijke kwaliteit door een referent maakt standaard onderdeel uit van ons kwaliteitsbeleid.

Het project 'Reproductiemeetnet Kustbroedvogels' wordt uitgevoerd in het kader van de wettelijke onderzoekstaken binnen het thema Informatievoorziening Natuur, gecoördineerd door het ministerie van Landbouw, Natuur en Voedselkwaliteit, en is onderdeel van het trilaterale monitoring programma TMAP. Het hiervoor benodigde veldwerk wordt gecoördineerd door Sovon Vogelonderzoek Nederland, in samenwerking met Wageningen Marine Research. Het onderzoek zou zonder de inzet van veel vrijwilligers van Sovon niet kunnen worden uitgevoerd.

Contactpersoon bij LNV voor de projecten die onder de Informatievoorziening Natuur vallen is Karst Jaarsma. Contactpersoon bij de WOT Natuur en Milieu, thema Informatievoorziening Natuur, is Anne Schmidt van Wageningen Environmental Research.

Het rapport is binnen Wageningen Marine Research beoordeeld door Sander Glorius. Binnen WOT Natuur \& Milieu is het rapport beoordeeld door Ruud Bink. Deze reviews hebben geleid tot verbeteringen van het document.

De auteurs bedanken allen voor hun bijdrage aan het tot stand komen van deze rapportage.

Akkoord Extern contactpersoon

functie: Beleidsmedewerker Trilaterale Samenwerking in de Waddenzee

naam: Karst Jaarsma

datum: $\quad 05-06-2020$

Akkoord Intern contactpersoon

naam: Anne Schmidt

datum: $\quad 02-06-2020$ 
Uitvoering van het Meetnet Reproductie in de Waddenzee is alleen mogelijk dankzij de bereidwillige medewerking van de terreinbeheerders en een groot aantal vrijwilligers (zowel gegevensverzameling als logistieke ondersteuning). In 2018 ging het om de volgende personen en organisaties:

\section{Texel:}

Bernard Spaans, Marc Plomp, Cor Smit en Giel Witte (VWG Texel), Dick Schermer en Rob Sier (beide Staatsbosbeheer), Martin de Jong (Noordkop Groen), Jenny Cremer (WMR), Lieuwe Dijksen (Sovon/VWG Texel), Eric Menkveld en Jitske Esselaar (Natuurmonumenten) en Bob Loos (VWG Texel).

\section{Vlieland:}

Peter de Boer (Sovon), Carl Zuhorn (Staatsbosbeheer Regio Noord), Petra de Goeij (Rijksuniversiteit Groningen/NIOZ/) en Henk-Jan van der Kolk (Nederlands Instituut voor Ecologie).

\section{Terschelling:}

Sjouke Scholten (Sovon), Anno Smit en Arjan Zonderland (SBB)

\section{Ameland:}

Ricus Engelmoer, Jan de Jong, Richard Kiewiet en Arjan Verbiest (It Fryske Gea), Johan Krol (Natuurcentrum Ameland), Jeffrey Huizenga (Staatsbosbeheer), Jelle Postma en Kees Oosterbeek (beide Sovon).

\section{Schiermonnikoog:}

Kees Oosterbeek, Romke Kleefstra \& Symen Deuzeman (Sovon), Petra de Goeij (Rijksuniversiteit Groningen/NIOZ), Erik Jansen (Natuurmonumenten).

\section{Rottumerplaat:}

Bart Ebbinge, Doortje Ebbinge-Dallmeijer, Nelly van Brederode en Hans Roersma, Sjoerd Dirksen $(\dagger)$, Hella Smit, Ali en Harry Horn - allen vogelwachters Staatsbosbeheer Regio Noord. Jaap Kloosterhuis, Jasper Schut en Dennis Moerkerken (allen Staatsbosbeheer Regio Noord).

\section{Griend:}

Date Lutterop \& Giny Kasemir, Erik Jansen (Natuurmonumenten).

\section{Noord-Hollandse kust:}

Roelf Hovinga (Landschap Noord-Holland), Lieuwe Dijksen (Sovon).

\section{Groninger kust en Dollard:}

Derick Hiemstra (Avifauna Groningen), Peter de Boer en Romke Kleefstra (beide Sovon), Arjan Hendriks, Silvan Puijman en Dirk Brul (allen Stichting Het Groninger Landschap), Kees Koffijberg (Avifauna Groningen/Sovon), Allix Brenninkmeijer (Provincie Groningen), Japke van Assen, Leo Bruinzeel en Daan Bos (Altenburg \& Wymenga) en Maarten Loonen (Arctisch Centrum, Rijksuniversiteit Groningen).

De schippers van MS Harder Freek-Jan de Wal en Jan Kostwinner (Waddenunit, Ministerie van LNV) willen we hartelijk danken voor de logistiek voor de bewakers van Rottumeroog en Rottumerplaat en de tocht naar De Hond.

Alle terreinbeheerders, Staatsbosbeheer, Natuurmonumenten, Het Noord-Hollands Landschap, It Fryske Gea en Het Groninger Landschap en Groningen Seaports worden bedankt voor het verlenen van toestemming om in hun terreinen gegevens te verzamelen.

Adriaan Gmelig-Meyling en Tom van der Meij (CBS) verzorgden de berekening van de trends in aantallen broedparen in het kader van het Netwerk Ecologische Monitoring. 
146 Arets, E.J.M.M., J.W.H van der Kolk, G.M. Hengeveld, J.P. Lesschen, H. Kramer, P.J. Kuikman \& M.J. Schelhaas (2019). Greenhouse gas reporting of the LULUCF sector in the Netherlands. Methodological background, update 2019.

147 Bruggen, C. van, A. Bannink, C.M. Groenestein, J.F.M. Huijsmans, L.A. Lagerwerf, H.H. Luesink, S.M. van der Sluis, G.L. Velthof \& J. Vonk (2019). Emissies naar lucht uit de landbouw in 2017. Berekeningen met het model NEMA.

148 Lagerwerf, L.A., A. Bannink, C. van Bruggen, C.M. Groenestein, J.F.M. Huijsmans, J.W.H. van der Kolk, H.H. Luesink, S.M. van der Sluis, G.L. Velthof \& J. Vonk (2019). Methodology for estimating emissions from agriculture in the Netherlands. Calculations of $\mathrm{CH} 4, \mathrm{NH} 3, \mathrm{~N} 2 \mathrm{O}$, NOX, NMVOC, PM10, PM2.5 and CO2 with the National Emission Model for Agriculture (NEMA) - update 2019.

149 Bakker, G., M. Heinen, H.P.A. Gooren, W.J.M. de Groot, F.B.T. Assinck \& E.W.J. Hummelink (2019). Hydrofysische gegevens van de bodem in de Basisregistratie Ondergrond (BRO) en het Bodemkundig Informatie Systeem (BIS); Update 2018.

150 IJsseldijk, L.L., M.J.L. Kik, \& A. Gröne (2019). Postmortaal onderzoek van bruinvissen (Phocoena phocoena) uit Nederlandse wateren, 2018. Biologische gegevens, gezondheidsstatus en doodsoorzaken.

151 Daamen, W.P., A.P.P.M. Clerkx \& M.J. Schelhaas (2019). Veldinstructie Zevende Nederlandse Bosinventarisatie (2017-2021); Versie 2.0.

152 Bikker, P., L.B. Šebek, C. van Bruggen \& O. Oenema (2019). Stikstof- en fosfaatexcretie van gangbaar en biologisch gehouden landbouwhuisdieren. Herziening excretieforfaits Meststoffenwet 2019.

153 Berg, F. van den, H. Baveco \& E.L. Wipfler (2019). User manual for SAFE (Select Application date For Evaluation) to support the use of the GEM scenarios for cultivations in glasshouses; Version 1.1

154 Os, J. van, L.J.J. Jeurissen en H.H. Ellen (2019). Rekenregels pluimvee voor de Landbouwtelling; Verantwoording van het gebruik van het Identificatie- \& Registratiesysteem.

155 Brouwer, F. \& D.J.J. Walvoort (2019). Basisregistratie Ondergrond (BRO) Actualisatie bodemkaart; Herkartering van de veengebieden in Eemland

156 Sanders, M.E., R.J.H.G. Henkens \& D.M.E. Slijkerman (2019). Convention on Biological
Diversity; Sixth National Report of the Kingdom of the Netherlands.

157 Kuiters, A.T., G.A. de Groot, D.R. Lammertsma H.A.H. Jansman, J. Bovenschen, M.C. Boerwinkel \& M. Laar (2019). Genetische monitoring van de Nederlandse otterpopulatie; Ontwikkeling van populatieomvang en genetische status 2018/2019.

158 Sanders, M.E. \& H.A.M. Meeuwsen (2019). Basisbestand Natuur en Landschap.

159 Visser, T., H.A.M Meeuwsen \& Th.C.P. Melman (2019). MNP-(Model for Nature Policy) Agrarisch; Uitwerking voor scenario's uit de Natuurverkenning 2020.

160 Jong, A. de, A. Poot \& P.I. Adriaanse (2019). Impact analysis for the purpose of the introduction of DROPLET version 1.3.2.

161 Westerink, J., T.A. de Boer, M. Pleijte \& R.A.M. Schrijver (2019). Kan een goede boer natuurinclusief zijn?; De rol van culturele normen in een beweging richting natuurinclusieve landbouw.

162 Buijs, A.E., F.G. Boonstra (2020). Natuurbeleid betwist; Visies op legitimiteit en natuurbeleid.

163 Haas, W. de, J.L.M. Donders, T.J.M. Mattijssen (2019). Natuur in conflict; Botsende waarden waarheden en belangen in het natuurbeheer.

164 Berg, F. van den, A. Tiktak, D. van Kraalingen \& J.J.T.I. Boesten (2019). User manual for FOCUSPEARL version 5.5.5.

165 Glorius, S.T., A. Meijboom, J. Schop \& J.T. van der Wal (2019). Ontwikkeling van enkele droogvallende mosselbanken in de Nederlandse Waddenzee; situatie 2018.

166 Pedroli, B, During, R. (2019). De paradox van een maakbare natuur - ingebakken en omstreden; Betekenis culturele identiteit voor draagvlak natuurbeleid en -beheer.

167 Walvoort, D.J.J., M. Knotters, F.M. van Egmond (2019). Interpolatie, aggregatie en desaggregatie van ruimtelijke bodemgegevens in de Basisregistratie Ondergrond (BRO).

168 Arets, E.J.M.M., J.W.H van der Kolk, G.M. Hengeveld, J.P. Lesschen, H. Kramer, P.J. Kuikman \& M.J. Schelhaas (2020). Greenhouse gas reporting of the LULUCF sector in the Netherlands. Methodological background, update 2020.

170 Bos-Groenendijk, G.I., C.A.M van Swaay (2020). Habitatrichtlijnrapportage 2019: Annex B Habitatrichtlijnsoorten; Achtergronddocument.

171 Janssen, J.A.M. (red.), R.J. Bijlsma (red.), G.H.P. Arts, M.J. Baptist, S.M. Hennekens, B. de Knegt, T. van der Meij, J.H.J. Schaminée, A.J. 
van Strien, S. Wijnhoven, T.J.W. Ysebaert (2020). Habitatrichtlijnrapportage 2019: Annex $D$ Habitattypen. Achtergronddocument.

172 Van Kleunen, A., M. van Roomen, E. van Winden, M. Hornman, A. Boele, C. Kampichler, D. Zoetebier, H. Sierdsema \& C. van Turnhout (2020). Vogelrichtlijnrapportage 2013-2018 van Nederland - status en trends van soorten.

173 Glorius, S.T., A. Meijboom (2020). Ontwikkeling van de bodemdiergemeenschap in de geulen van referentiegebied Rottum;

Tussenrapportage 13 jaar na sluiting (najaar 2018).

174 Kuindersma, W., D. van Doren, R. Arnouts, D.A. Kamphorst, J.G. Nuesink, E. de Wit-de Vries (2020). Realisatie Natuurnetwerk door provincies. Achtergrondstudie bij de Tweede Lerende Evaluatie Natuurpact.

175 Bouwma, I.M., D.A. Kamphorst, D. van Doren, T.A. de Boer, A.E. Buijs, C.M. Goossen, J.L.M. Donders, J.Y. Frissel, S. van Broekhoven (2020). Provinciaal beleid voor maatschappelijke betrokkenheid bij natuur het beleid nader bekeken in 8 casussen. Achtergrondstudie bij de Tweede Lerende Evaluatie Natuurpact.

176 Gerritsen, A.L., H. Agricola, C. Aalbers, J. van Os (2020). Natuur en landbouw verbinden. Achtergrondstudie bij de Tweede Lerende Evaluatie Natuurpact.
177 Brouwer, F., D.J.J. Walvoort (2020). Basisregistratie Ondergrond (BRO) Actualisatie bodemkaart. Herkartering van de veengebieden aan de flanken van de Utrechtse Heuvelrug.

178 Bruggen, C. van, A. Bannink, C.M. Groenestein, J.F.M. Huijsmans, L.A. Lagerwerf, H.H. Luesink, G.L. Velthof \& J. Vonk (2020). Emissies naar lucht uit de landbouw, 1990-2018; Emissies van ammoniak, stikstofoxide, lachgas, methaan, niet-methaan vluchtige organische stoffen, fijnstof en koolstofdioxide uit kalkmeststoffen - Berekeningen met het model NEMA.

179 Knegt, de B., M. Pleijte, E. de Wit-de Vries, I. Bouwma, F. Kistenkas, W. Nieuwenhuizen (2020). Samenhang Klimaatakkoord en natuurbeleid. Proces en implementatie van het Klimaatakkoord door provincies en maatschappelijke partijen en de potentiële effecten op biodiversiteitsdoelen van de Vogelen Habitatrichtlijn.

180 Mattijssen T.J.M., M. Pleijte, J. Dengerink, T. Koster, M. Visscher (2020). Indicatoren voor burgerbetrokkenheid bij natuur: een zoektocht naar nieuwe aanknopingspunten voor monitoring.

183 Koffijberg K., P. de Boer, S.C.V. Geelhoed, J. Nienhuis, K. Oosterbeek, J. Postma (2020). Broedsucces van kustbroedvogels in de Waddenzee in 2018 



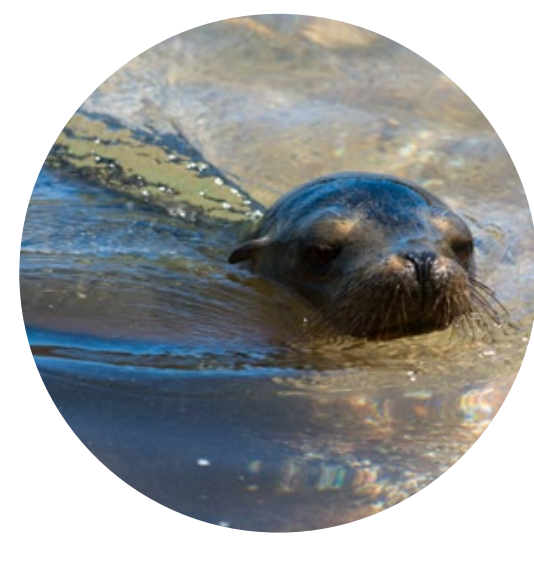

Thema Informatievoorziening Natuur Wettelijke Onderzoekstaken Natuur \& Milieu

Postbus 47

6700 AA Wageningen

T (0317) 485471

E info.wnm@wur.nl

ISSN 2352-2739

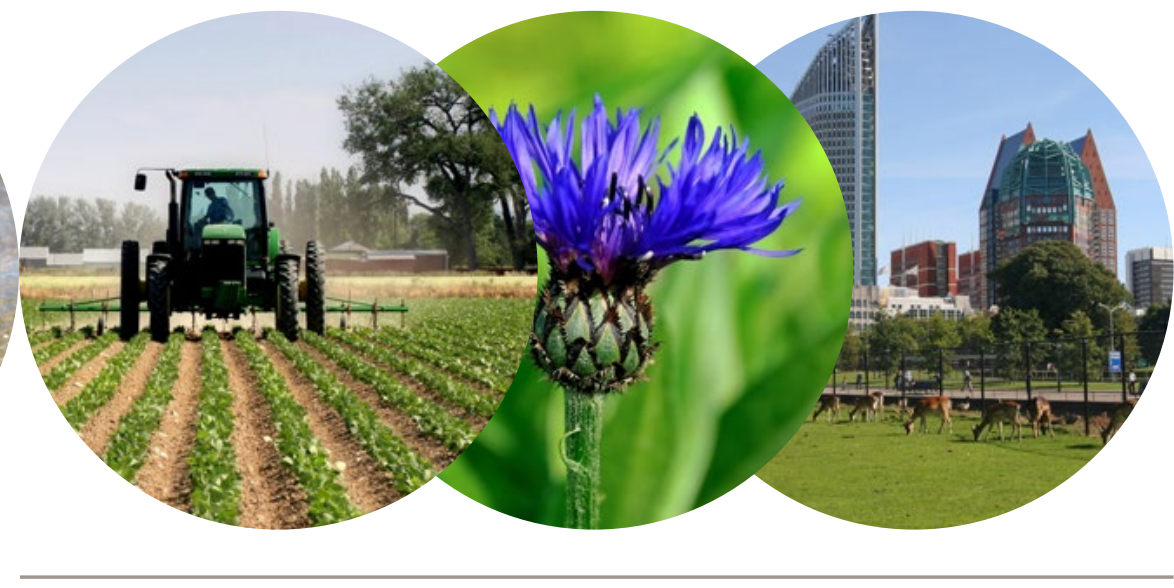

De missie van Wageningen University \& Research is 'To explore the potential of nature to improve the quality of life'. Binnen Wageningen University \& Research bundelen 9 gespecialiseerde onderzoeksinstituten van Stichting Wageningen Research en Wageningen University hun krachten om bij te dragen aan de oplossing van belangrijke vragen in het domein van gezonde voeding en leefomgeving. Met ongeveer 30 vestigingen, 5.000 medewerkers en 10.000 studenten behoort Wageningen University \& Research wereldwijd tot de aansprekende kennisinstellingen binnen haar domein. De integrale benadering van de vraagstukken en de samenwerking tussen verschillende disciplines vormen het hart van de unieke Wageningen aanpak. 